\title{
Investigation of $\mathrm{CeTi}_{2} \mathrm{O}_{6}$ - and $\mathrm{CaZrTi}_{2} \mathrm{O}_{7}$-containing glass-ceramic composite materials
}

\author{
Elham Paknahad and Andrew P. Grosvenor* \\ Department of Chemistry, University of Saskatchewan, Saskatoon, SK, Canada, S7N 5C9
}

* Author to whom correspondence should be addressed

E-mail: andrew.grosvenor@usask.ca

Phone: (306) 966-4660

Fax: (306) 966-4730 


\section{Abstract}

Glass-ceramic composite materials are being investigated for numerous applications (i.e. textile, energy storage, nuclear waste immobilization applications, etc.) due to the chemical durability and flexibility of these materials. Borosilicate and Fe-Al-borosilicate glass-ceramic composites containing brannerite $\left(\mathrm{CeTi}_{2} \mathrm{O}_{6}\right)$ or zirconolite $\left(\mathrm{CaZrTi}_{2} \mathrm{O}_{7}\right)$ crystallites were synthesized at different annealing temperatures. The objective of this study was to understand the interaction of brannerite or zirconolite-type crystallites within the glass matrix and to investigate how the local structure of these composite materials changed with changing synthesis conditions. Powder Xray diffraction (XRD) and Backscattered electron (BSE) microprobe images have been used to study how the ceramic crystallites dispersed in the glass matrix. X-ray absorption near edge spectroscopy (XANES) spectra were also collected from all glass-ceramic composite materials. Examination of Ti K-, Ce L $3^{-}, \mathrm{Zr} \mathrm{K}-, \mathrm{Si} \mathrm{L}_{2,3}$, Fe K-, and Al L2,3-edge XANES spectra from the glass-ceramic composites have shown that the annealing temperature, glass composition, and the loading of the ceramic crystallites in the glass matrix can affect the local environment of the glass-ceramic composite materials. A comparison of the glass-ceramic composites containing brannerite or zirconolite crystallites has shown that similar changes in the long-range and local structure of these composite materials occur when the synthesis conditions to form these materials or the composition are changed.

Keywords: Glass-ceramic composite materials; Nuclear waste immobilization applications; Brannerite; Zirconolite; Borosilicate and Fe-Al-borosilicate glass. 


\section{Introduction}

Glass-ceramic composite materials containing crystalline phases within a glass matrix have received attention for numerous applications in strategic fields such as medicine (bioactive composite as bone replacement and drug delivery systems), photonics, energy storage, aerospace, textiles, and waste management. ${ }^{1-6}$ The safe and secure immobilisation of nuclear waste is one of the applications that composite materials have received attention for. ${ }^{4-10}$ Extensive studies in the field of nuclear waste sequestration have led to the development of wasteforms based on crystalline ceramics, ${ }^{11-13}$ amorphous glasses, ${ }^{14,15}$ and glass-ceramic composite materials. ${ }^{4-6,16}$ Glass-ceramic composite wasteforms have the potential to provide significantly higher waste loading, enhanced thermal stability, and flexibility compared to glass or ceramic wasteforms alone. ${ }^{6-10,16-20}$ For example, radioactive waste elements incorporated in the highly durable crystalline phase within the glass matrix would benefit from a double barrier (ceramic + glass). ${ }^{4,10,18-20}$ Studying the local structure of these materials is a crucial step to the development of wasteforms for nuclear waste sequestration. ${ }^{9,10,17-20}$

Borosilicate glasses containing both silicon and boron as network formers were proposed as the first generation wasteform for the immobilisation of high level nuclear waste (HLW) due to the stability and flexibility of the silicate network. ${ }^{7,14,21,22}$ It has been suggested that the presence of transition metals (e.g., Fe) in the borosilicate glass can increase the structural stability of these wasteforms. ${ }^{23-25}$ The release of $\beta$-particles and $\gamma$-rays from radioactive elements can lead to the formation of electron-hole pairs in the glass wasteforms and the presence of $\mathrm{Fe}$ in the glass has been suggested to be able to trap electron-hole pairs. ${ }^{23,25}$ This could result in the materials having an increased resistance to radiation induced structural damage. ${ }^{23-25}$ 
Titanate ceramics (e.g., SYNROC) are another option for HLW sequestration applications. ${ }^{26-29}$ Brannerite, having the composition $\mathrm{MTi}_{2} \mathrm{O}_{6}(\mathrm{M}=\mathrm{U}, \mathrm{Th}, \mathrm{Ce})$, is one possible host matrix for the immobilization of actinide-bearing radioactive waste. ${ }^{30-33}$ The brannerite crystal structure belongs to the monoclinic system, with space group $\mathrm{C} 2 / \mathrm{m}$. The structure consists of alternating columns of edge-sharing $\mathrm{MO}_{6}$ octahedra with regular shapes and distorted layers of edge-sharing $\mathrm{TiO}_{6}$ octahedra that are corner sharing with the $\mathrm{MO}_{6}$ octahedra (Figure 1a). ${ }^{30,31}$ Cerium acts as an actinide simulator element in $\mathrm{MTi}_{2} \mathrm{O}_{6}$ because $\mathrm{Ce}$ has a similar ionic radius, coordination environment, and electronic structure to some actinide elements. ${ }^{31-33}$ Cerium is not a good simulator element for $\mathrm{U}$ because $\mathrm{Ce}$ can be easily reduced to $\mathrm{Ce}^{3+}$ while $\mathrm{U}^{3+}$ is rare; however, $\mathrm{Ce}$ is a good simulator element for $\mathrm{Pu}^{31-33}$ Moreover, the crystalline structure of brannerite $\left(\mathrm{MTi}_{2} \mathrm{O}_{6}\right)$ is a good example for immobilizing uranium-bearing radioactive waste because $\mathrm{UTi}_{2} \mathrm{O}_{6}$ can hold a significant concentration of uranium ( $\sim 55 \mathrm{wt} \%$ per formula unit). ${ }^{32,33}$

Zirconolite-based ceramics are considered as one of the most promising wasteforms for HLW sequestration applications. ${ }^{35,36}$ Previous studies have demonstrated that zirconolite can immobilise both actinides and fission products in the crystal lattice for the long term. . $^{37,38}$ Zirconolite refers specifically to $\mathrm{CaZrTi}_{2} \mathrm{O}_{7}$, which has a monoclinic structure (space group $\mathrm{C} 2 / \mathrm{c})$. The zirconolite crystal structure forms a monoclinic system that is made up layers of $\mathrm{TiO}_{6}$ and $\mathrm{TiO}_{5}$ polyhedra with $\mathrm{Ca}^{2+}\left(8\right.$ coordinate) and $\mathrm{Zr}^{4+}$ (7 coordinate) ions located in the large interstitial sites between these layers (Figure 1b). ${ }^{39}$

The objective of this study is to understand how ceramic crystallites behave within a glass matrix, and to investigate how the local structure of these composite materials change as a result of synthesis conditions. Borosilicate and Fe-Al-borosilicate glass-ceramic composites containing brannerite $\left(\mathrm{CeTi}_{2} \mathrm{O}_{6}\right)$ or zirconolite $\left(\mathrm{CaZrTi}_{2} \mathrm{O}_{7}\right)$ crystallites were synthesized at 
different annealing temperatures to study the effect of composition and annealing temperature on the local and long-range structure of these materials. Electron microscopy and powder X-ray diffraction (XRD) have been used to study the dispersion of ceramic crystallites in the glass matrix. X-ray absorption near-edge spectroscopy (XANES) was used to investigate changes in the local structure of these materials by collecting Ti K-, $\mathrm{Ce} \mathrm{L}_{3^{-}}, \mathrm{Zr} \mathrm{K}-, \mathrm{Si} \mathrm{L}_{2,3^{-}}, \mathrm{Fe} \mathrm{K}-$, and Al L $2,3-$ edge XANES spectra. ${ }^{40}$

\section{Experimental}

\subsection{Synthesis}

Brannerite was synthesized using the ceramic method. $\mathrm{CeO}_{2}$ (Alfa Aesar, 99.9\%) and $\mathrm{TiO}_{2}$ (anatase, Alfa Aesar, 99.6\%) powders were mixed in stoichiometric amounts, pelleted at 6 MPa and heated in air for six days at $1325{ }^{\circ} \mathrm{C}$ with intermediate mixing and pelleting. Zirconolite, nominally $\mathrm{CaZrTi}_{2} \mathrm{O}_{7}$ was also synthesized by the ceramic method using a stoichiometric mixture of $\mathrm{CaO}, \mathrm{ZrO}_{2}$ (Alfa Aesar, 99.7\%), and $\mathrm{TiO}_{2}$ (rutile, Alfa Aesar, 99.9\%) powders. Calcium carbonate $\left(\mathrm{CaCO}_{3}, \mathrm{ACS},>99 \%\right)$ was heated in air first at $900{ }^{\circ} \mathrm{C}$ for one day to decompose to $\mathrm{CaO}$. $\mathrm{CaZrTi}_{2} \mathrm{O}_{7}$ was synthesized by mixing the binary oxides using an agate mortar followed by pressing the mixture into a pellet using a pressure of $6 \mathrm{MPa}$, and then heating the pellet in air for two days at $1400{ }^{\circ} \mathrm{C}$. The sample was then quench cooled in air, ground, pelleted, and re-heated at $1400{ }^{\circ} \mathrm{C}$ for another two days. Diffraction patterns from the ceramics (brannerite and zirconolite) were collected using a PANalytical Empyrean X-ray diffractometer and a Co $\mathrm{K} \alpha_{1,2} \mathrm{X}$-ray source at room temperature. Phase analysis was performed using the High Score Plus software package. ${ }^{41}$

Borosilicate glass (BG) and Fe-Al borosilicate glass (FABG) were synthesized by the ceramic method. The compositions of the borosilicate and Fe-Al borosilicate glasses are listed in 
Table 1. Appropriate amounts of the respective metal oxide powders were mixed, pressed into pellets at $6 \mathrm{MPa}$ and annealed at $1100{ }^{\circ} \mathrm{C}$ for 1 hour in graphite crucibles. Labels used to name the glasses and glass-ceramic composites studied are listed in Table 2.

Glass-ceramic composite materials containing brannerite in borosilicate glass or Fe-Al borosilicate glass $\left(\mathrm{BG} / \mathrm{FABG}-\mathrm{CeTi}_{2} \mathrm{O}_{6}\right)$ and zirconolite in borosilicate glass or Fe-Al borosilicate glass (BG/FABG-CaZrTi $\left.{ }_{2} \mathrm{O}_{7}\right)$ were synthesized by the ceramic method. The separately synthesized glass and ceramic materials were mixed and then annealed to form glass-ceramic composite materials. Different loadings of $\mathrm{CeTi}_{2} \mathrm{O}_{6}$ or $\mathrm{CaZrTi}_{2} \mathrm{O}_{7}(10$ to $40 \mathrm{wt} \%)$ were mixed with appropriate amounts of borosilicate glass (BG) or Fe-Al-borosilicate glass (FABG) to form the glass-ceramic composites, pressed into pellets at $6 \mathrm{MPa}$, and then placed in graphite crucibles. The pellets were heated in air at 1100 or $750{ }^{\circ} \mathrm{C}$ for 1 hour. All composite materials were quench cooled in air and were observed to be beads after annealing at 1100 or $750{ }^{\circ} \mathrm{C}$ (see Figure 2). It has been reported previously that borosilicate glasses have softening and liquefication points above 800 and $1000{ }^{\circ} \mathrm{C}$, respectively; however, these temperatures can be affected by the glass composition..$^{21,42,43}$ The observation of both the glasses and glass-ceramic composites forming beads after annealing at $750{ }^{\circ} \mathrm{C}$ indicates that the glass compositions studied here had a liquid state at this temperature. The annealing temperatures used in this study were chosen so as to study how such significant differences in temperature impact the local and longrange structure of the composite materials.

\subsection{Electron microprobe analysis}

The surface morphologies and chemical compositions of the samples were examined by collecting backscattered electron images (BSE) and energy dispersive X-ray (EDX) maps. BSE images and EDX maps were collected using a JEOL 8600 electron microprobe instrument. The 
glass-ceramic composite beads were embedded in a polymer resin and the surfaces of the beads were polished using diamond paste. The samples were coated with carbon to reduce charging effects. ${ }^{44}$ BSE images were collected from the composite materials using a magnification of 1000X. Samples were mapped by EDX to determine the chemical composition at different locations.

\subsection{XANES}

\subsubsection{Ti K-, Zr K-, and Ce $\mathrm{L}_{3}$-edges}

Ti K-, Ce $\mathrm{L}_{3}$ - and $\mathrm{Zr}$ K-edge XANES spectra were collected using the Canadian Light Source/X-ray Science Division Collaborative Access Team (CLS@APS, Sector 20) bending magnetic beamline (20BM) located at the Advanced Photon Source (APS), Argonne National Laboratory. ${ }^{45} \mathrm{~A} \mathrm{Si}(111)$ double crystal monochromator with a harmonic rejection mirror was used, which provides a photon flux of $\sim 10^{11}$ photons $/ \mathrm{s} .{ }^{45}$ The resolution of the spectra is $0.7 \mathrm{eV}$ at $4966 \mathrm{eV}$ (Ti K-edge), $0.9 \mathrm{eV}$ at $5723 \mathrm{eV}$ (Ce L3-edge), and $2.6 \mathrm{eV}$ at $17998 \mathrm{eV}$ (Zr K-edge). ${ }^{45}$ The samples were finely ground and sealed between layers of Kapton tape, and the thickness was adjusted by varying the number of layers of tape to maximize the absorption signal. Multiple scans of each spectrum were collected in fluorescence yield or transmission mode. The transmission spectra were recorded using ionization chambers filled with $\mathrm{He}_{(\mathrm{g})}$ and $\mathrm{N}_{2(\mathrm{~g})}$ to achieve optimal absorption-edge step heights and signal-to-noise ratios. ${ }^{46}$ The spectra were also collected in fluorescence mode using a single element vortex silicon detector. XANES spectra were collected using a step size of $0.15 \mathrm{eV} / \mathrm{step}$ through the $\mathrm{Ti} \mathrm{K}$ - and $\mathrm{Ce}_{\mathrm{L}}$-edges and 0.5 eV/step through the $\mathrm{Zr} \mathrm{K}$-edge. The Ti K-edge spectra were calibrated using Ti metal (4966 eV) and the $\mathrm{Ce}_{2}$-edge spectra were calibrated using $\mathrm{Cr}$ metal $(5989 \mathrm{eV}){ }^{33,44} \mathrm{The} \mathrm{Zr} \mathrm{K}$-edge spectra 
were calibrated using $\mathrm{Zr}$ foil as a reference standard with the absorption-edge energy set to $17998.0 \mathrm{eV} \cdot{ }^{47}$

\subsubsection{Fe K-edge}

The Soft X-ray Microcharacterization Beamline (SXRMB, 06B1-1) located at the Canadian Light Source (CLS) was used to collect the Fe K-edge XANES spectra from Fe-Al borosilicate glass composite materials using a Si (111) monochromator. ${ }^{48}$ This beamline provides a photon flux of $10^{11}$ photons/s and a resolution of $0.7 \mathrm{eV}$ at $7112 \mathrm{eV}{ }^{48}$ The samples were sealed between layers of Kapton tape and the spectra were collected in fluorescence yield and transmission modes using a step size of $0.15 \mathrm{eV}$ through the Fe K-edge. The spectra were calibrated using Fe foil $(7112 \mathrm{eV}) .{ }^{48}$

\subsubsection{Si and Al L2,3-edges}

The $\mathrm{Si}$ and $\mathrm{Al} \mathrm{L}_{2,3}$-edge XANES spectra were collected from the composite materials using the Variable Line Spacing-Plane Grating Monochromator (VLS-PGM) beamline at the CLS. ${ }^{49}$ The samples were prepared by placing ground powder on carbon tape. The spectra were collected in total fluorescence yield (TFY) mode using a step size of $0.05 \mathrm{eV}$ through the Si and Al L 2,3-edges. The spectra were calibrated using elemental Si for the $\mathrm{Si} \mathrm{L}_{2,3}$-edge $(99.4 \mathrm{eV})$ and Al metal for the Al L2,3-edge (72.5 eV). ${ }^{44,49}$ All XANES spectra were normalized and analyzed using the Athena software program. ${ }^{50}$

\section{Results and discussion}

\subsection{Powder X-ray diffraction}

Powder XRD patterns from the glass-ceramic composite materials were collected to obtain information about the long-range structure of these materials. The XRD patterns from the glasses (BG and FABG) annealed at different temperatures are shown in Figures $3 \mathrm{a}$ and $3 \mathrm{~b}$. 
Unique powder patterns were observed depending on if the glass-ceramic composite materials were annealed at $750{ }^{\circ} \mathrm{C}$ or $1100{ }^{\circ} \mathrm{C}$, as has been observed previously. ${ }^{44}$ The patterns from the glasses annealed at $1100{ }^{\circ} \mathrm{C}\left(\mathrm{BG}-1100^{\circ} \mathrm{C}\right.$ and $\left.\mathrm{FABG}-1100^{\circ} \mathrm{C}\right)$ show only a broad hump which confirms the amorphous structure of these materials. However, the diffraction pattern from the borosilicate glass annealed at $750{ }^{\circ} \mathrm{C}$ contains peaks that correspond to the presence of quartz $\left(\mathrm{SiO}_{2}\right)$, whereas no such peaks were observed in the XRD pattern from the Fe-Al borosilicate glass annealed at $750{ }^{\circ} \mathrm{C}$. The stabilization of the amorphous structure of the Fe-Al borosilicate glass sample was assumed to be a result of the presence of $\mathrm{Al} .{ }^{44}$ It was shown previously that $\mathrm{Al}$ is responsible for stabilizing the amorphous structure of the Fe-Al-borosilicate glass. ${ }^{44,51}$ Aluminum is a network intermediate and can behave as a network former or a network modifier. ${ }^{8,44,51-53} \mathrm{Al}$ is known to substitute into 4- to 6- coordinate positions, including those normally occupied by $\mathrm{Si}$, and can aid in the formation of the glass. ${ }^{52-54}$

Powder XRD patterns were collected from composite materials containing different amounts of $\mathrm{CeTi}_{2} \mathrm{O}_{6}$ in borosilicate glass annealed at 750 or $1100{ }^{\circ} \mathrm{C}$ (Figures $4 \mathrm{a}$ and $4 \mathrm{~b}$ ). Diffraction patterns from the $\mathrm{BG}-\mathrm{CeTi}_{2} \mathrm{O}_{6}$ composites annealed at $750{ }^{\circ} \mathrm{C}$ contain peaks from $\mathrm{CeTi}_{2} \mathrm{O}_{6}$ and quartz, as well as a broad hump that is representative of the amorphous glass matrix. The patterns from the composite materials annealed at $1100{ }^{\circ} \mathrm{C}$ (Figures $4 \mathrm{~b}$ ) shows that peaks from brannerite only started to appear in diffraction patterns of the composite materials when $40 \mathrm{wt} \%$ of $\mathrm{CeTi}_{2} \mathrm{O}_{6}$ was loaded in the glass matrix. These observations indicate that a significant amount of the brannerite crystallites dissolved in the glass matrix after annealing at $1100{ }^{\circ} \mathrm{C}$.

XRD patterns were also collected from the $\mathrm{BG}-\mathrm{CaZrTi}_{2} \mathrm{O}_{7}$ composite materials containing different amounts of $\mathrm{CaZrTi}_{2} \mathrm{O}_{7}$ annealed at 750 or $1100{ }^{\circ} \mathrm{C}$ (Figures $5 \mathrm{a}$ and $5 \mathrm{~b}$ ). 
Examination of the patterns from the composite materials annealed at $1100{ }^{\circ} \mathrm{C}$ showed that the minimum loading of $\mathrm{CaZrTi}_{2} \mathrm{O}_{7}$ when peaks representing zirconolite started to appear in the diffraction patterns was $40 \mathrm{wt} \%$ (Figure $5 \mathrm{~b}$ ). Diffraction peaks from zirconolite were observed in all patterns from $\mathrm{BG}-\mathrm{CaZrTi}_{2} \mathrm{O}_{7}$ annealed at $750{ }^{\circ} \mathrm{C}$ regardless of loading (Figure 5a); however, peaks representing the presence of quartz were not observed. The lack of peaks corresponding to the presence of quartz is likely a result of $\mathrm{Ca}$ from zirconolite that had dissolved in the glass matrix, acting as a network modifier. ${ }^{8,37,38,53}$ These results suggest that a low annealing temperature (i.e., $750{ }^{\circ} \mathrm{C}$ ) is more favourable to the formation of a composite material with a negligible amount of the ceramic having dissolved in the glass matrix.

XRD patterns from Fe-Al borosilicate glass composite materials containing brannerite or zirconolite annealed at either 750 or $1100{ }^{\circ} \mathrm{C}$ are shown in Figures S1 and S2 in the supporting information. Diffraction patterns from these composite materials were observed to be similar to the patterns from borosilicate glass-based composite materials. These results indicate that the type of glass used (i.e., borosilicate or Fe-Al borosilicate) does not influence how the annealing temperature affected the average structure of these composite materials.

\subsection{Electron microscopy and EDX}

BSE images from the borosilicate glass composite materials ( $\mathrm{BG}-\mathrm{CeTi}_{2} \mathrm{O}_{6} / \mathrm{CaZrTi}_{2} \mathrm{O}_{7}$ ) annealed at either 750 or $1100{ }^{\circ} \mathrm{C}$ are shown in Figure 6. The BSE images from the glass-ceramic composite materials (see Figure 6) show that the brannerite or zirconolite crystallites (bright area) can be differentiated from the glass matrix (dark area). Moreover, air bubbles formed during annealing were also observed in the images from these materials.

The BSE images from the composite materials annealed at $1100^{\circ} \mathrm{C}$ (Figures $6 \mathrm{~b}$ and $6 \mathrm{~d}$ ) contained smaller crystallites when compared to the images from the composite materials 
annealed at $750^{\circ} \mathrm{C}$ (Figures 6a and 6c). Examination of EDX maps (see Figures S3 and S4 in supporting information) from the composite materials containing brannerite annealed at $1100{ }^{\circ} \mathrm{C}$ shows that the glass-like regions contained high concentrations of $\mathrm{Ce}$ and $\mathrm{Ti}$ (Figure S4). The presence of $\mathrm{Ce}$ and $\mathrm{Ti}$ was observed only in the ceramic crystallites when an annealing temperature of $750{ }^{\circ} \mathrm{C}$ was used to form the glass-ceramic composite materials (Figure S3). These results confirm that more brannerite/zirconolite crystallites dissolved in the glass matrix after annealing at higher temperatures (i.e., 1100 vs $750^{\circ} \mathrm{C}$ ). These observations are in good agreement with the analysis of the XRD patterns (vide supra).

\subsection{XANES analysis}

Examination of Ti K-, Ce L $3_{3}^{-}, \mathrm{Zr} \mathrm{K}-, \mathrm{Si} \mathrm{L}_{2,3}$, Fe K-, and Al L L,3-edge XANES spectra from the glass-ceramic composite materials has allowed for a study of how the annealing temperature, glass composition, and the loading of the ceramic crystallites affected the local environment of the glass-ceramic composites.

\subsubsection{Ti K-edge XANES}

Ti K-edge XANES spectra were collected from the $\mathrm{BG}-\mathrm{CeTi}_{2} \mathrm{O}_{6}$ and $\mathrm{BG}-\mathrm{CaZrTi}_{2} \mathrm{O}_{7}$ composite materials containing 10, 20, and $30 \mathrm{wt} \%$ of $\mathrm{CeTi}_{2} \mathrm{O}_{6}$ or $\mathrm{CaZrTi}_{2} \mathrm{O}_{7}$ annealed at either 750 or $1100{ }^{\circ} \mathrm{C}$ (see Figures 7 and 8). Examination of the Ti K-edge spectra shows how the loading of the ceramic $\left(\mathrm{CeTi}_{2} \mathrm{O}_{6}\right.$ or $\left.\mathrm{CaZrTi}_{2} \mathrm{O}_{7}\right)$ in the glass matrix and the annealing temperature used can affect the local coordination environment of $\mathrm{Ti}$ in the composite materials. These spectra result from $1 \mathrm{~s} \rightarrow 3 \mathrm{~d}$ (quadrapolar; pre-edge $(\mathrm{A})$ ) and $1 \mathrm{~s} \rightarrow 4 \mathrm{p}$ (dipolar; main-edge (B and C)) transitions. ${ }^{33,44,55}$ The pre-edge region (features $A_{1}, A_{2}$ and $A_{3}$ ) contains peaks resulting from local $1 \mathrm{~s} \rightarrow 3 \mathrm{~d} \mathrm{t} \mathrm{t}_{\mathrm{g}}\left(\mathrm{A}_{1}\right)$ and $1 \mathrm{~s} \rightarrow 3 \mathrm{~d} \mathrm{eg}{ }^{*}\left(\mathrm{~A}_{2}\right)$ transitions, as well as a third peak $\left(\mathrm{A}_{3}\right)$ that results from a non-local, intersite-hybrid excitation involving the transition of 1 s electrons to unoccupied $3 \mathrm{~d}$ 
orbitals from a next-nearest-neighbour $\mathrm{Ti}$ ion that overlaps with $4 \mathrm{p}$ orbitals from the absorbing $\mathrm{Ti}$ ion through bridging $\mathrm{O} 2 \mathrm{p}$ orbitals. ${ }^{33,44,55,56}$

The intensity of the pre-edge feature (A) increases while the energy (B) and intensity (C) of the main-edge features decrease with decreasing $\mathrm{Ti}$ coordination number $(\mathrm{CN}) .{ }^{56-60}$ The quadrupolar transition (pre-edge (A)) is normally forbidden by dipole selection rules but it becomes allowed with mixing of $d$ and p orbitals. ${ }^{33,44,56-60}$ An increase in the intensity of the preedge peak is observed for a site without a centre of symmetry (i.e., $\mathrm{TiO}_{4}$ tetrahedron or a $\mathrm{TiO}_{5}$ square pyramid) because of the mixing $3 \mathrm{~d}$ with $4 \mathrm{p}$ orbitals, which provides some dipole allowed character to the quadrupolar transition. The pre-edge peak can therefore be used to infer the $\mathrm{Ti}$ CN. ${ }^{33,44,56-60}$ The energy and intensity of the main-edge features (B and C) can change because of variations in $\mathrm{CN}$ and/or oxidation state. ${ }^{55,61}$ Feature $\mathrm{B}$ can shift to a lower energy because of a decrease in $\mathrm{CN}{ }^{56-58} \mathrm{~A}$ lower $\mathrm{CN}$ results in greater final state relaxation effects due to the presence of fewer electrons in the first coordination-shell leading to a shift down in absorption energy. ${ }^{56}$ The intensity of feature $\mathrm{C}$ is also affected by changes in the $\mathrm{CN}$. As the $\mathrm{CN}$ decreases, this reduces the number of $\mathrm{Ti} 4 \mathrm{p}-2 \mathrm{p} \mathrm{O}$ final states available for $1 \mathrm{~s}$ electrons to be excited to, resulting in a decrease in the intensity of feature C. ${ }^{56}$ Feature B (and C) can also shift in energy with changing oxidation state. An increase in the oxidation state will result in fewer electrons being available to screen the nuclear charge and, therefore, more energy is required to excite core electrons leading to an increase in the observed absorption energy. ${ }^{44,55,61}$

Examination of the $\mathrm{Ti}$ K-edge spectra from the $\mathrm{BG}-\mathrm{CeTi}_{2} \mathrm{O}_{6}$ composite materials annealed at either 750 (Figure 7a) or $1100{ }^{\circ} \mathrm{C}$ (Figure 7b) shows that the intensity and energy of the pre-edge and main-edge features changed by varying the loading of brannerite in the glass matrix or by varying the annealing temperature used to form these composite materials. It was 
observed that the intensity of the pre-edge feature (A) increased while the energy (B) and intensity (C) of the main-edge features decreased with increasing annealing temperature or decreasing brannerite loading in the composite materials when compared to the spectrum from $\mathrm{CeTi}_{2} \mathrm{O}_{6}$ (see Figures $7 \mathrm{a}$ and $7 \mathrm{~b}$ ). These changes in the Ti K-edge XANES spectra were attributed to a decrease in the $\mathrm{CN}$ of $\mathrm{Ti}^{4+} \cdot{ }^{56-60}$ It is recognized that the shift down in energy of feature $\mathrm{B}$ could also suggest that $\mathrm{Ti}^{4+}$ is reduced in the composite materials, however a reduction in the Ti oxidation should also lead to a decrease in the intensity of the pre-edge peak (feature A) which was not observed. The observed increase in the intensity of feature A and decrease in energy of feature $\mathrm{B}$ when comparing the composite materials to $\mathrm{CeTi}_{2} \mathrm{O}_{6}$ can only be attributed to a lowering of the average $\mathrm{Ti} \mathrm{CN} .^{33,44,56-60}$ Titanium adopts a lower $\mathrm{CN}$ when incorporated in the glass versus when it is incorporated in brannerite. ${ }^{44}$ Moreover, the average $\mathrm{Ti} \mathrm{CN}$ is lower in the $\mathrm{BG}-\mathrm{CeTi}_{2} \mathrm{O}_{6}$ composites annealed at $1100{ }^{\circ} \mathrm{C}$ compared to the composites annealed at $750{ }^{\circ} \mathrm{C}$, further confirming that more brannerite dissolved in the glass matrix after annealing at $1100^{\circ} \mathrm{C}$.

Ti K-edge XANES spectra from the $\mathrm{BG}-\mathrm{CaZrTi}_{2} \mathrm{O}_{7}$ composite materials annealed at either 750 or $1100^{\circ} \mathrm{C}$ are shown in Figures $8 \mathrm{a}$ and $8 \mathrm{~b}$. The intensity of the pre-edge feature (A) increased with increasing the annealing temperature or decreasing zirconolite loading in the composite materials when compared to the spectrum from $\mathrm{CaZrTi}_{2} \mathrm{O}_{7}$ (see Figures $8 \mathrm{a}$ and $8 \mathrm{~b}$ ). These observations indicate that $\mathrm{Ti}$ occupies a lower $\mathrm{CN}$ when incorporated in the glass than in ceramic. ${ }^{44}$ The composite materials containing zirconolite annealed at $1100{ }^{\circ} \mathrm{C}$ show a lower $\mathrm{Ti}$ $\mathrm{CN}$ compared to the composite materials annealed at $750^{\circ} \mathrm{C}$ because more zirconolite dissolved in the glass after annealing at $1100^{\circ} \mathrm{C}$. The comparison of the Ti K-edge spectra from the composite materials containing brannerite or zirconolite crystallites show that similar changes in the coordination environment of $\mathrm{Ti}$ occur when the synthesis conditions were changed. These 
observations show that the local structure of $\mathrm{Ti}$ in the glass-ceramic composite materials is affected strongly by the annealing temperature which agree with the powder XRD and electron microscopy results discussed above.

Ti K-edge spectra were also collected from the composite materials containing $30 \mathrm{wt} \%$ $\mathrm{CeTi}_{2} \mathrm{O}_{6}$ and $30 \mathrm{wt} \% \mathrm{CaZrTi}_{2} \mathrm{O}_{7}$ in $\mathrm{Fe}-\mathrm{Al}$ borosilicate glass annealed at either 750 or $1100{ }^{\circ} \mathrm{C}$ to determine if the type of glass used affects the local coordination environment of $\mathrm{Ti}$ in these composite materials (see Figures S5 and S6 in supporting information). Comparing the spectra from the $\mathrm{BG}-30 \mathrm{wt} \% \mathrm{CeTi}_{2} \mathrm{O}_{6}$ and $\mathrm{FABG}-30 \mathrm{wt} \% \mathrm{CeTi}_{2} \mathrm{O}_{6}$ composites annealed at either 750 (Figure S5a) or $1100{ }^{\circ} \mathrm{C}$ (Figure S5b) shows that the type of glass used does not affect the behavior of $\mathrm{Ti}$ in these glass-ceramic composite materials. Comparison of the spectra from BG and $\mathrm{FABG}$ composite materials containing $30 \mathrm{wt} \% \mathrm{CaZrTi}_{2} \mathrm{O}_{7}$ annealed at either 750 (Figure S6a) or $1100{ }^{\circ} \mathrm{C}$ (Figure S6b) also shows that the behavior of Ti is not affected by changing the type of glass used to form these composite materials.

\subsubsection{Ce L3-edge XANES}

Ce $\mathrm{L}_{3}$-edge XANES spectra were collected from the $\mathrm{BG}-\mathrm{CeTi}_{2} \mathrm{O}_{6}$ composite materials annealed at either 750 or $1100{ }^{\circ} \mathrm{C}$ to study how the local environment of $\mathrm{Ce}$ changes in these materials and are shown in Figure 9. Four features are observed in these spectra from $\mathrm{Ce}^{4+}$, which are labelled as $B_{1}, B_{2}, B_{3}$, and $B_{4}$ (see Fig. 9). The spectra result from a quadrupolar $2 p$ $\rightarrow 4 \mathrm{f}$ transition $\left(\mathrm{B}_{1}\right)$ and three dipolar $2 \mathrm{p} \rightarrow 5 \mathrm{~d}$ transitions where the final-states of Ce changes to $4 \mathrm{f}^{2}\left(\mathrm{~B}_{2}\right), 4 \mathrm{f}^{\mathrm{l}}\left(\mathrm{B}_{3}\right)$, and $4 \mathrm{f}^{0}\left(\mathrm{~B}_{4}\right) .^{33,62}$

Examination of the $\mathrm{Ce} \mathrm{L}_{3}$-edge XANES spectra from the $\mathrm{BG}^{-} \mathrm{CeTi}_{2} \mathrm{O}_{6}$ composite materials shows that the intensity and energy of the pre-edge and main-edge features changed when the annealing temperature was changed from 750 to $1100{ }^{\circ} \mathrm{C}$. The observed changes in the 
Ce $\mathrm{L}_{3}$-edge spectra from the composite materials are a result of a variation in the Ce oxidation state. ${ }^{62,63}$ The presence of features $\mathrm{B}_{3}$ and $\mathrm{B}_{4}$ are indicative of $\mathrm{Ce}^{4+}$ while the observation of an intense $\mathrm{B}_{2}$ peak is indicative of the presence of $\mathrm{Ce}^{3+} \cdot 33,62,63$ Comparing the intensity of features $\mathrm{B}_{2}$ , $\mathrm{B}_{3}$ and $\mathrm{B}_{4}$ in the spectra shows that the average Ce oxidation state is lower in the composite materials annealed at $1100{ }^{\circ} \mathrm{C}$ versus the composite materials annealed at $750{ }^{\circ} \mathrm{C}$. The changes in the Ce oxidation state can be attributed to a temperature-dependant equilibrium between $\mathrm{O}$ and $\mathrm{Ce}\left(2 \mathrm{Ce}^{4+}+\mathrm{O}^{2-} \rightleftharpoons 2 \mathrm{Ce}^{3+}+\mathrm{O}_{2}\right) \cdot{ }^{33,62,63}$ As the annealing temperature of the system increases, the equilibrium shifts towards the reduced state of $\mathrm{Ce}$ (i.e., $\left.\mathrm{Ce}^{3+}\right) \cdot{ }^{33,62,63}$ This effect was observed to be much more severe when $\mathrm{Ce}$ is contained in the glass matrix than in the ceramic $\left(\mathrm{CeTi}_{2} \mathrm{O}_{6}\right)$ as a result of brannerite dissolving in the glass matrix when an annealing temperature of $1100{ }^{\circ} \mathrm{C}$ was used. ${ }^{33}$ The major oxidation state of Ce was observed to be $4+$ for all composite materials annealed at $750{ }^{\circ} \mathrm{C}$ while the presence of $\mathrm{Ce}^{3+}$ increased with decreasing loading of brannerite in the $\mathrm{BG}-\mathrm{CeTi}_{2} \mathrm{O}_{6}$ composite materials annealed at $1100{ }^{\circ} \mathrm{C}$. This observation confirms that brannerite dissolved in the glass matrix when the composite materials were annealed at $1100{ }^{\circ} \mathrm{C}$ but only up to a certain loading (30-40 wt $\%$ ) after which some crystalline brannerite was observed to be present.

\subsubsection{Zr K-edge XANES}

$\mathrm{Zr}$ K-edge spectra were collected from the composite materials containing $\mathrm{CaZrTi}_{2} \mathrm{O}_{7}$ in order to understand how the $\mathrm{Zr} \mathrm{CN}$ in the $\mathrm{BG}-\mathrm{CaZrTi}_{2} \mathrm{O}_{7}$ composites was affected by the synthesis conditions used to form these materials (Figure 10). A distinct pre-edge peak (1s $\rightarrow 4 d$ ) is not observed in the Zr K-edge XANES spectra because of the low resolution of the spectra and the decreased separation between $\mathrm{Zr} 4 \mathrm{~d}$ and $5 \mathrm{p}$ orbitals when compared to first row transition metals like $\mathrm{Ti}^{64,65}$ Although the resolution of the pre-edge peak in the Zr K-edge spectra makes 
it difficult to investigate changes in $\mathrm{Zr} \mathrm{CN}$, the main-edge features are sensitive to $\mathrm{CN}$ changes. ${ }^{64,65}$ The spectrum from zirconolite exhibited a broad maximum in the main edge at around $18017 \mathrm{eV}$, which is in good agreement with previous studies of materials containing 7coordinate $\mathrm{Zr}\left(\mathrm{Zr}^{[7]}\right) \cdot{ }^{64-67}$ The intensity, energy, and lineshape of the pre-edge and main-edge features of the spectra were observed to change as the annealing temperature of the composite materials was varied. The observed changes in the Zr K-edge XANES spectra (i.e., large differences in the spectral lineshape) have been shown previously to result from variations in the $\mathrm{CN}$ of $\mathrm{Zr}^{4+} \cdot{ }^{65-67} \mathrm{~A}$ double peak in the main edge with a maximum around $18030 \mathrm{eV}$ is observed in the Zr K-edge XANES spectra from materials containing six-coordinate Zr while a single broad peak in the main edge is observed for materials containing seven-coordinate Zr. ${ }^{64-67}$ These observations fit well with the observations of Zr K-edge XANES spectra from the composite materials presented here and indicate that $\mathrm{Zr}$ adopts a lower $\mathrm{CN}$ when it is incorporated in the glass matrix than in zirconolite crystallites. ${ }^{68}$ Moreover, comparing the Zr K-edge XANES spectra from the glass-ceramic composite materials shows that the average $\mathrm{Zr} \mathrm{CN}$ is lower in the composites annealed at $1100{ }^{\circ} \mathrm{C}$ compared to the composite materials annealed at $750{ }^{\circ} \mathrm{C}$. As the annealing temperature increased, the $\mathrm{CN}$ of $\mathrm{Zr}$ decreased in the composites because of zirconolite crystallites dissolving in the glass matrix.

\subsubsection{Si L2,3-edge XANES}

Si L 2,3 -edge XANES spectra were collected to study how the local structure of $\mathrm{Si}$ in the glass was affected by varying the loading of the ceramic, annealing temperature, and the type of glass used to form the composite materials. The $\mathrm{Si} \mathrm{L}_{2,3}$-edge XANES spectra contain two features that result from $2 p \rightarrow 3 s$ (Feature D) and $2 p \rightarrow 3 d$ (Feature E) transitions, respectively. The low-energy feature (D) is split into two peaks $\left(\mathrm{D}_{1}\right.$ and $\left.\mathrm{D}_{2}\right)$ due to spin-orbit splitting. ${ }^{69,70}$ 
It was observed in previous studies of $\mathrm{Si}_{2,3}$ edge XANES spectra that features $\mathrm{D}$ and $\mathrm{E}$ become narrower to higher energy on going from amorphous silicate to quartz. ${ }^{44,70-72}$ The spectra from materials containing amorphous silicates (i.e. glass) have broader peaks to lower energy compared to their crystalline analogues, which can be attributed to the lack of long range order in amorphous silicates. ${ }^{70-72}$ As the materials change from amorphous silicates to quartz, a more ordered $\mathrm{SiO}_{4}{ }^{4-}$ tetrahedral bond network would be present, leading to an increase in the degeneracy of Si-O conduction states. This effect results in features $\mathrm{D}$ and $\mathrm{E}$ becoming narrower to higher energy. $44,70-72$

The Si $\mathrm{L}_{2,3}$-edge XANES spectra from the composite materials containing different amounts of $\mathrm{CeTi}_{2} \mathrm{O}_{6}$ or $\mathrm{CaZrTi}_{2} \mathrm{O}_{7}$ in the glass $(\mathrm{BG}$ and $\mathrm{FABG}$ ), and annealed at different temperatures are shown in Figures 11, 12 and S7. The spectra from the corresponding glasses $(\mathrm{BG}$ or $\mathrm{FABG})$ are also presented in these figures. The width of the spectral features $(\mathrm{D}, \mathrm{E})$ from the composite materials were observed to decrease with increasing loading of the ceramic, decreasing the annealing temperature, or varying the type of glass used to form these materials (i.e., BG vs FABG). The observed changes in the spectra can be attributed to changes in the ordering of the glass in the composites as a result of the partial crystallization of the glass matrix and variations in the glass composition as a result of ceramic crystallites dissolving in the glass network leading to next nearest-neighbour effects between the metal cations and $\mathrm{Si}^{44,70-73}$ The next nearest-neighbour metal cation (M) in the Si-O-M bond can influence the strength, length, and bonding characteristics of the Si-O bond. ${ }^{70-73}$ The observed changes in the $\mathrm{Si} \mathrm{L}_{2,3}$ edge XANES spectra from the composite materials indicate that the variation in the loading of $\mathrm{CeTi}_{2} \mathrm{O}_{6}$ or $\mathrm{CaZrTi}_{2} \mathrm{O}_{7}$, the annealing temperature, and the glass composition affect the silicate network. The Si $\mathrm{L}_{2,3}$-edge spectra from the BG-composite materials showed more changes when 
compared to the spectra from the FABG-composite materials. These observations indicate that the silicate environment in the borosilicate glass matrix is affected to a greater degree than in the Fe-Al borosilicate glass matrix because of the partial crystallization of the borosilicate glass and next nearest-neighbour effects due to the variation in the glass composition. ${ }^{44}$ Moreover, the features $\mathrm{D}$ and $\mathrm{E}$ in the spectra from BG-CeTi2 $\mathrm{O}_{6}-750{ }^{\circ} \mathrm{C}$ were observed to be sharper when compared to the spectra from $\mathrm{BG}-\mathrm{CaZrTi}_{2} \mathrm{O}_{7}-750{ }^{\circ} \mathrm{C}$. This observation can be attributed to the presence of quartz in the borosilicate glass composite materials containing $\mathrm{CeTi}_{2} \mathrm{O}_{6}$ annealed at $750{ }^{\circ} \mathrm{C}$, as quartz was not detected to be present in the $\mathrm{BG}-\mathrm{CaZrTi}_{2} \mathrm{O}_{7}-750{ }^{\circ} \mathrm{C}$ analogues by XRD.

\subsubsection{Fe K-edge XANES}

Fe K-edge XANES spectra were collected to study how the redox chemistry of Fe in the $\mathrm{Fe}-\mathrm{Al}$ borosilicate glass matrix can affect the local structure of the composite materials. The Fe K-edge XANES spectra contain pre-edge $(1 \mathrm{~s} \rightarrow 3 \mathrm{~d}, \mathrm{~A})$ and main-edge $(1 \mathrm{~s} \rightarrow 4 \mathrm{p}$, B and C) excitations that resemble the features observed in Ti K-edge XANES spectra. ${ }^{74-76}$ The Fe K-edge spectra from the composite materials (FABG-30 wt $\% \mathrm{CeTi}_{2} \mathrm{O}_{6}$ and $\mathrm{FABG}-30 \mathrm{wt} \% \mathrm{CaZrTi}_{2} \mathrm{O}_{7}$ ) annealed at 750 or $1100{ }^{\circ} \mathrm{C}$ are shown in Figures $13 \mathrm{a}$ and $13 \mathrm{~b}$.

The Fe K-edge spectra from the composite materials containing $30 \mathrm{wt} \% \mathrm{CeTi}_{2} \mathrm{O}_{6}$ or $\mathrm{CaZrTi}_{2} \mathrm{O}_{7}$ in $\mathrm{Fe}-\mathrm{Al}$ borosilicate glass showed a significant shift of the main edge (feature B) to lower energy along with a decrease in the pre-edge peak intensity (feature A) in the composite materials annealed at $1100{ }^{\circ} \mathrm{C}$ versus those annealed at $750{ }^{\circ} \mathrm{C}$. The observed decrease in the intensity of feature A and energy of feature B can only be attributed to a variation in Fe oxidation

state based on the reasons provided above when discussing the Ti K-edge XANES spectra (section 3.3.1). 
The Fe K-edge XANES spectra indicate that the oxidation state of Fe in the composite materials annealed at $1100{ }^{\circ} \mathrm{C}$ was reduced to $2+$ while the oxidation state of $\mathrm{Fe}$ in the composite materials annealed at $750{ }^{\circ} \mathrm{C}$ was $3+.{ }^{77-79}$ The observed change in Fe oxidation state with varying annealing temperature is a result of a redox reaction and a temperature-dependant equilibrium between $\mathrm{O}$ and $\mathrm{Fe}\left(4 \mathrm{Fe}^{3+}+2 \mathrm{O}^{2-} \rightleftharpoons 4 \mathrm{Fe}^{2+}+\mathrm{O}_{2}\right)$. The equilibrium shifts towards $\mathrm{Fe}^{2+}$ when the annealing temperature increases. ${ }^{44,77-79}$

\subsubsection{Al L2,3-edge XANES}

Al $\mathrm{L}_{2,3}$-edge XANES spectra were collected from the FABG-CeTi ${ }_{2} \mathrm{O}_{6}$ composite materials annealed at either 750 or $1100{ }^{\circ} \mathrm{C}$ to study the local environment of $\mathrm{Al}$ (see Figure S8 in supporting information). The spectra contain two features (D and E) that result from $2 \mathrm{p} \rightarrow 3 \mathrm{~s}$ and $2 \mathrm{p} \rightarrow 3 \mathrm{~d}$ transitions, respectively. ${ }^{80}$ It has been shown previously that $\mathrm{Al} \mathrm{L}_{2,3}$-edge XANES spectra are sensitive to changes in the $\mathrm{CN}$ of $\mathrm{Al} .{ }^{80}$ In the present work, examination of the spectra from the composite materials show negligible changes in the spectral features. These observations indicate that the local structure of $\mathrm{Al}$ in the composite materials is not affected considerably by varying the loading of the ceramic or the annealing temperature used to form these composite materials.

\section{Conclusions}

A good insight into the local structure of glass-ceramic composite materials has been achieved by the investigation of borosilicate and Fe-Al-borosilicate glass-ceramic composites containing brannerite or zirconolite crystallites. These investigations have shown that the $\mathrm{CeTi}_{2} \mathrm{O}_{6}$ or $\mathrm{CaZrTi}_{2} \mathrm{O}_{7}$ crystallites can dissolve in the glass matrix depending on the ceramic loading, the glass composition, and the annealing temperature used to form these composite materials. It was observed that the $\mathrm{CeTi}_{2} \mathrm{O}_{6}$ or $\mathrm{CaZrTi}_{2} \mathrm{O}_{7}$ crystallites can dissolve significantly in 
the glass matrix when annealed at high temperature. Examination of $\mathrm{Ti} \mathrm{K}-$ and $\mathrm{Zr} \mathrm{K}$-edge XANES spectra from the composite materials indicated that applying a lower annealing temperature is desired for the formation of a composite material with only a small fraction of the ceramic crystallites $\left(\mathrm{CeTi}_{2} \mathrm{O}_{6}\right.$ or $\left.\mathrm{CaZrTi}_{2} \mathrm{O}_{7}\right)$ having dissolved in the glass matrix. The $\mathrm{Si} \mathrm{L}_{2,3-}$ edge XANES spectra showed that the ordering of the silicate network can be affected depending upon the loading of $\mathrm{CeTi}_{2} \mathrm{O}_{6}$ or $\mathrm{CaZrTi}_{2} \mathrm{O}_{7}$, annealing temperature, and the type of glass used to

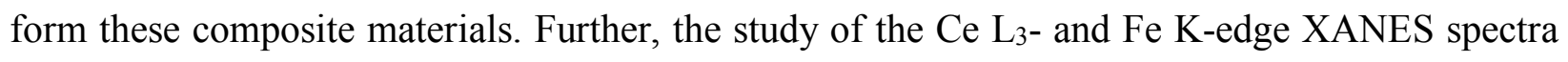
from the Fe-Al-borosilicate composites showed that the oxidation state of $\mathrm{Ce}$ and $\mathrm{Fe}$ in the glassceramic composite materials is strongly affected by the annealing temperature. The comparison of glass-ceramic composite materials containing brannerite and zirconolite has shown that similar changes in the long-range and local structure of these composite materials occurs as a result of changing the synthesis conditions. The study of these composite materials will provide a better understanding of how to develop and design materials as nuclear wasteform materials as well as for other applications.

\section{Acknowledgements}

This project was funded by the Natural Sciences and Engineering Research Council (NSERC) of Canada through a Discovery grant awarded to APG. EP would like thank to the University of Saskatchewan for financial support. Mr. Blaine Novakovski and Mr. Tom Bonli (Department of Geology, U of S) are thanked for their help in preparing samples for electron microprobe analysis and performing the measurements. Dr. Zou Finfrock and Dr. Matthew Ward are thanked for their help carrying out XANES measurements using the 20BM beamline (CLS@APS). The CLS@APS facilities are supported by the US Department of Energy-Basic Energy Sciences and the Canadian Light Source (CLS). Dr. Lucia Zuin is thanked for her 
support in carrying out XANES experiments using the VLS-PGM (11ID-2) beamline at the CLS.

Dr. Yongfeng $\mathrm{Hu}$ and $\mathrm{Ms}$. Aimee Maclennan are thanked for their support in carrying out XANES experiments using the SXRMB (06B1-1) beamline at CLS. The CLS is supported by the Canada Foundation for Innovation, the Natural Sciences and Engineering Research Council, Western Economic Diversification Canada, the National Research Council of Canada, the Canadian Institutes of Health Research, the Government of Saskatchewan, and the University of Saskatchewan.

\section{References}

(1) Boccaccini, A. R.; Ferraris, M.; Reece, M. J.; Salvo, M. Adv. Appl. Ceram. 2015, 114, 67536761.

(2) El-Meliegy, E.; Noort, R. V. Glasses and Glass Ceramics for Medical Applications; Springer Science: New Yourk, USA, 2012.

(3) Wei, X.; Yan, H.; Wang, T.; Hu, Q.; Viola, G.; Grasso, S.; Jiang, Q.; Jin, L.; .Xu, Zh.; Reece, M. J. J. Appl. Phys. 2013, 113, 023510-17.

(4) Digeos, A. A.; Valdez, J. A.; Sickafus, K. E.; Atiq, S.; Grimes, R. W.; Boccaccini, A. R. J. Mater. Sci. 2003, 38, 1597-1604.

(5) Lee, W. E.; Ojovan, M. I.; Stennett, M. C.; Hyatt, N. C. Adv. Appl. Ceram. 2006, 105, 1-12.

(6) Loiseau, P.; Caurant, D. J. Nucl. Mater. 2010, 402, 38-54.

(7) Boccaccini, A. R.; Bernardo, E.; Blain, L.; Boccaccini, D. N. J. Nucl. Mater. 2004, 327, 148158.

(8) Caurant, D.; Loiseau, P.; Bardez, I.; Gervais, C. J. Mater. Sci. 2007, 42, 8558-8570.

(9) Amoroso, J.; Marra, J. C.; Tang, M.; Lin, Y.; Chen, F.; Su, D.; Brinkman, K. S. J. Nucl. Mater. 2014, 454, 12-21. 
(10) Zhang, Y.; Zhang, Z.; Thorogood, G.; Vance, E. R. J. Nucl. Mater. 2013, 432, 545-547.

(11) Ewing, R. C. Can. Mineral. 2005, 43, 2099-2116.

(12) Laverov, N. P.; Yudintsev, S. V.; Livshits, T. S.; Stefanovsky, S. V.; Lukinykh, A. N.; Ewing, R. C. J. Geochemistry International. 2010, 48, 1-14.

(13) Lian, J.; Wang, L. M.; Lumpkin, G. R.; Ewing. R. C. Nuclear Instruments and Methods in Physics Research B. 2002, 191, 565-570.

(14) Raj, K.; Kaushik, C. P. Materials Science and Engineering. 2009, 2, 1-6.

(15) Ojovan, M. I.; Lee, W. E. Metallurgical and Materials Transactions. 2011, 42, 837-851.

(16) Ojovan, M. I.; Juoi, J. M.; Lee, W. E. J Pak Mater Soc. 2008, 2, 72-76.

(17) Martin, C.; Ribet, I.; Frugier, P.; Gin, S. J. Nucl. Mater. 2007, 366, 277-287.

(18) Ewing, R. C.; Webert, W. J.; Clinard, F. W. Prog. Nucl. Energy. 1995, 29, 63-121.

(19) Pace, S.; Cannillo, V.; Wu, J.; Boccaccini, D. N.; Seglem, S.; Boccaccini, A. R. J. Nucl. Mater. 2005, 341, 12-18.

(20) Boccaccini, A. R.; Afiq, S.; Grimes, R. W. Adv. Eng. Mater. 2003, 5, 501-508.

(21) Marples, J. A. C. Glass Technol. 1988, 29, 230.

(22) Ojovan, M. I.; Lee, W. E. An Introduction to Nuclear Waste Immobilization; Elsevier: Amsterdam, 2005.

(23) McGann, O. J.; Bingham, P. A.; Hand, R. J.; Gandy, A. S.; Kavcic, M.; Itnik, M. Z.; Bucar, K.; Edge, R.; Hyatt, N. C. J. Nucl. Mater. 2012, 429, 353-367.

(24) Malchukova, E.; Boizot, B.; Petite, G.; Ghaleb, D. Eur. Phys. J. Appl. Phys. 2009, 45, 10701-10710.

(25) McGann, O. J.; Gandy, A. S.; Bingham, P. A.; Hand, R. J.; Hyatt, N. C. MRS Proc. 2013, $1518,41-46$. 
(26) Lutze, W.; Ewing, R. C. Radioactive Waste Forms for the Future; Elsevier: Amsterdam, 1988.

(27) Ringwood, A. E.; Oversby, V. M.; Kesson, E. S.; Sinclair, W.; Ware, N.; Hibberson, W. Nucl. Chem. Waste Manage. 1981, 2, 287-305.

(28) Ringwood, A. E.; Kesson, E. S.; Ware, N. G.; Hibberson, W. Nature. 1979, 278, 219-223.

(29) Sickafus, K. E.; Grimes, R. W.; Valdez, J. A.; Cleave, A.; Tang, M.; Ishimaru, M.; Corish, S.; Stanek, C. R.; Uberuaga, B. P. Nature Mater. 2007, 6, 217-223.

(30) Lumpkin, G. R.; Smith, K. L.; Blackford, M. G. J. Nucl. Mater. 2001, 289, 177-187.

(31) Helean, K. B.; Navrotsky, A.; Lumpkin, G. R.; Colella, M.; Lian, J.; Ewing, R. C.; Ebbinghaus, B.; Catalano, J. G. J. Nucl. Mater. 2003, 320, 231-244.

(32) Lopez, C.; Deschanels, X.; Bart, J. M.; Boubals, J. M.; Den Auwer, C.; Simoni, E. J. Nucl. Mater. 2003, 312, 76-80.

(33) Huynh, L. T.; Eger, Sh. B.; Walker, J. D. S.; Hayes, J. R.; Gaultois, M. W.; Grosvenor, A. P. Solid State Sciences. 2012, 14, 761-767.

(34) Momma K.; Izumi, F. J. Appl. Crystallogr. 2008, 41, 653-658.

(35) Stefanovsky, S. V.; Nikokov, B. S.; Omelianenko, B. I.; Yudintsev, S. V.; Yakushev, A. I. Phys. Chem. Mat. Treat. 1997, 111-117.

(36) Yudintsev, S. V.; Omelianenko, B. I.; Stefanovsky, S. V.; Ochkin, A. V.; Chizhevskaya, S. V. J. Adv. Mat. 1998, 91-100.

(37) Caurant, D.; Loiseau, P.; Bardez, I. Journal of Nuclear Materials. 2010, 407, 88-99.

(38) Zhang, Y.; Stewart, M. W. A.; Li, H.; Carter, M. L.; Vance, E. R.; Moricca, S. J. Nucl. Mater. 2009, 395, 69-74. 
(39) Salamat, A.; McMillan, P. F.; Firth, S.; Woodhead, K.; Hector, A. L.; Garbarino, G.; Stennett, M. C.; Hyatt, N. C. J. Inorg. Chem. 2013, 52, 1550-1558.

(40) De Groot, F. M. F. Chem. Rev. 2001, 101, 1779-1808.

(41) PANalytical B. V. X'Pert HighScore Plus.Version 3.0; Almelo: Netherlands, 2011.

(42) Wallenberger, F. T.; Watson, J. C.; Li, H. ASM: Composites, 2001, 21, 27-34.

(43) Hrma, P.; Schweiger, M. J.; Humrickhouse, C. J.; Moody, J. A.; Tate, R. T.; Rainsdon, T. T.; TeGrotenhuis, N. E.; Arrigoni, B. M.; Marcial, J.; Rodriguez, C. P.; Tincher, B. H. Ceramics - Silikáty, 2010, 54, 193-211.

(44) Aluri E. R.; Grosvenor, A. P. RSC Adv. 2015, 5, 10477-10486.

(45) Heald, S. M.; Brewe, D. L.; Stern, E. A.; Kim, K. H.; Brown, F. C.; Jiang, D. T.; Crozier, E. D.; Gordon, R. A. J. Synchrotron Rad. 1999, 6, 347-349.

(46) Aluri, E. R.; Hayes, J. R.; Walker, J. D. S.; Grosvenor, A. P. J. Phys. Chem. C. 2014, 15, 7910-7922.

(47) Thompson, A.; Attwood, D.; Gullikson, E.; Howells, M.; Kim, K. J.; Kirz, J.; Kortright, J.; Lindau, I.; Yanwei, L.; Pianetta, P.; Robinson, A.; Scofield, J.; Underwood, J.; Williams, G.; Winick, H. X-ray Data Booklet; Lawrence Berkeley National Laboratory: Berkeley, CA, 2001. (48) Hu, Y. F.; Coulthard, I.; Chevrier, D.; Wright, G.; Igarashi, R.; Sitnikov, A.; Yates, B. W.; Hallin, E. L; Sham, T. K.; Reininger, R.; Garrett, R.; Gentle, I.; Nugent, K.; Wilkins, S. AIP Conf. Proc. 2009, 1234, 343-346.

(49) Hu, Y. F.; Zuin, L.; Reininger, R.; Sham, T. K. AIP Conf. Proc. 2007, 879, 535-538.

(50) Ravel, B.; Newville, M. J. Synchrotron Rad. 2005, 12, 537-541.

(51) Singh, J.; Singh, D.; Singh, S. P.; Mudahar, G. S.; Thind, K. S. Mater. Phys. Mech. 2014, $19,9-15$. 
(52) Sen, S.; Youngman, R. E. J. Phys. Chem. B. 2004, 108, 7557-7564.

(53) Zachariasen, W. H. J. Am. Chem. Soc. 1932, 54, 3841-3850.

(54) Zheng, Q. J.; Youngman, R. E.; Hogue, C. L.; Mauro, J. C.; Potuzak, M.; Smedskjaer, M. M.; Yue, Y. Z. Phys. Rev. B. 2012, 86, 1-12.

(55) Cabaret, D.; Joly, Y.; Renevier, H.; Natoli, C. R. J. Synchrotron Rad. 1999, 6, 258-260.

(56) Gaultois, M. W.; Grosvenor, A. P. J. Mater. Chem. 2011, 21, 1829-1836.

(57) Farges, F.; Brown, G. E.; Rehr, J. J. Phys. Rev. B. 1997, 56, 1809-1819.

(58) Farges, F. Am. Mineral. 1997, 82, 44-50.

(59) Joly, Y.; Cabaret, D.; Renevier, H.; Natoli, C. R. Phys. Rev. Lett. 1999, 82, 2398-2401.

(60) Romano, C.; Paris, E.; Poe, B. T.; Giuli, G.; Dingwell, D. B.; Mottanai, A. American Mineralogist. 2000, 85, 108-117.

(61) Greaves, G. N.; Barrett, N. T.; Antonini, G. M.; Thornley, F. R.; Willis, B. T. M.; Steel, A. Am. Chem. Soc. 1989, 111, 4313-4324.

(62) Kotani, A.; Kvashnina, K.O.; Butorin, S.M.; Glatzel, P. J. Electron. Spectrosc. Rel. Phenom. 2001, 184, 210-215.

(63) Lopez, C.; Deschanels, X.; Bart, J. M.; Boubals, J. M.; Den Auwer, C.; Simoni, E. J. Nucl. Mater. 2003, 312, 76-80.

(64) Mountjoy, G.; Anderson, R.; Newport, R. J.; Smith, M. E. J. Condens. Matter. 2000, 12, 3505-3519.

(65) Gaultois, M. W.; Greedan, J. E.; Grosvenor, A. P. J. Electron Spectroscopy and Related Phenomena. 2011, 184, 192-195.

(66) Mountjoy, G.; Pickup, D. M.; Anderson, R.; Wallidge, G. W.; Holland, M. A.; Newport, R. J.; Smith, M. E. J. Phys. Chem. Chem. Phys. 2000, 2, 2455-2460. 
(67) Jollivet, P.; Calas, G.; Galoisy, L.; Angeli, F.; Bergeron, B.; Gin, S.; Ruffoni, M. P.; Trcera, N. Journal of Non-Crystalline Solids. 2013, 381, 40-47.

(68) Patzig, C.; Höche, T.; Hu, Y.; Ikeno, H.; Krause, M.; Dittmer, M.; Gawronski, A.; Rüssel, C.; Tanaka, I.; Henderson, G. S. Journal of Non-Crystalline Solids. 2014, 384, 47-54.

(69) Li, D.; Bancroft, G. M.; Kasrai, M.; Fleet, M. E.; Feng, X. H.; Tan, K. H.; Yang, B. X. Solid State Commun. 1993, 87, 613-617.

(70) Li, D.; Bancroft, G. M.; Kasrai, M.; Fleet, M. E.; Secco, R. A.; Feng, X. H.; Tan, K. H.; Yang B. X. Am. Mineral. 1994, 79, 622-632.

(71) Garvie, L. A. J.; Buseck, P. R. Am. Mineral. 1999, 84, 946-964.

(72) Harp, G. R.; Saldin, D. K.; Tonner, B. P. J. Condens. Matter. 1993, 5, 5377-5388.

(73) Sammynaiken, R.; Naftel, S. J.; Sham, T. K.; Cheah, K. W.; Averboukh, B.; Huber, R. Journal of applied physics. 2002, 92, 3000-3006.

(74) Hayes J. R.; Grosvenor, A. P. J. Alloys Comp. 2012, 537, 323-331.

(75) Sigrist, J. A.; Gaultois M. W.; Grosvenor, A. P. J. Phys. Chem. A. 2011, 115, 1908-1912.

(76) Westre, T. E.; Kennepohl, P.; Dewitt, J. G.; Hedman, B.; Hodgson K. O.; Solomon, E. I. J. Am. Chem. Soc. 1997, 119, 6297-6314.

(77) Magnien, V.; Neuville, D. R.; Cormier, L.; Roux, J.; Hazemann, J. L.; Pinet, O.; Richet, P. J. Nucl. Mater. 2006, 352, 190-195.

(78) Mehdikhani, B.; Borhani, G. H. Process. Appl. Ceram. 2013, 7, 117-121.

(79) Vickridge, I.; Pinet, O.; Richet, P. Geo. Cosmo. Acta. 2008, 72, 2157-2168.

(80) Walker, J. D. S.; Grosvenor, A. P. Inorg. Chem. 2013, 52, 8612-8620. 


\section{Tables}

Table 1: Compositions of the synthesized glasses.

\begin{tabular}{ccccccc}
\hline Glass & $\begin{array}{c}\mathrm{SiO}_{2} \\
(\mathbf{m o l} \%)\end{array}$ & $\begin{array}{c}\mathrm{B}_{2} \mathrm{O}_{3} \\
(\mathbf{m o l} \%)\end{array}$ & $\begin{array}{c}\mathrm{Na}_{2} \mathrm{O} \\
(\mathbf{m o l} \%)\end{array}$ & $\begin{array}{c}\mathrm{CaO} \\
(\mathbf{m o l} \%)\end{array}$ & $\begin{array}{c}\mathrm{Fe}_{2} \mathrm{O}_{3} \\
(\mathbf{m o l} \%)\end{array}$ & $\begin{array}{c}\mathrm{Al}_{2} \mathrm{O}_{3} \\
(\mathbf{m o l} \%)\end{array}$ \\
\hline Borosilicate (BG) & 63.5 & 16.9 & 16.5 & 3.1 & - & - \\
Fe-Al borosilicate & 55.5 & 16.9 & 16.5 & 3.1 & 3.0 & 5.0 \\
$($ FABG $)$ & & & & & &
\end{tabular}


Table 2: Labels used to name the glasses and glass-ceramic composites studied.

\begin{tabular}{|c|c|}
\hline Label & Sample description \\
\hline BG & Borosilicate glass \\
\hline FABG & Fe-Al-borosilicate glass \\
\hline $\mathrm{BG}-\mathrm{CeTi}_{2} \mathrm{O}_{6}-750 / 1100{ }^{\circ} \mathrm{C}$ & $\begin{array}{l}\text { Composite materials containing brannerite in } \\
\text { borosilicate glass annealed at either } 750 \text { or } \\
1100^{\circ} \mathrm{C}\end{array}$ \\
\hline $\mathrm{BG}-\mathrm{CaZrTi}{ }_{2} \mathrm{O}_{7}-750 / 1100^{\circ} \mathrm{C}$ & $\begin{array}{l}\text { Composite materials containing zirconolite in } \\
\text { borosilicate glass annealed at either } 750 \text { or } \\
1100^{\circ} \mathrm{C}\end{array}$ \\
\hline BG-XX wt $\% \mathrm{CeTi}_{2} \mathrm{O}_{6}$ or $\mathrm{CaZrTi}_{2} \mathrm{O}_{7}$ & $\begin{array}{l}\text { Composite materials containing } \mathrm{XX} w \mathrm{wt} \% \\
\text { brannerite or zirconolite in borosilicate glass }\end{array}$ \\
\hline FABG-XX wt $\% \mathrm{CeTi}_{2} \mathrm{O}_{6}$ or $\mathrm{CaZrTi}_{2} \mathrm{O}_{7}$ & $\begin{array}{l}\text { Composite materials containing } \mathrm{XX} \text { wt } \% \\
\text { brannerite or zirconolite in Fe-Al borosilicate } \\
\text { glass }\end{array}$ \\
\hline
\end{tabular}




\section{Figure Captions}

Figure 1: The monoclinic crystal structures of (a) $\mathrm{CeTi}_{2} \mathrm{O}_{6}$ and (b) $\mathrm{CaZrTi}_{2} \mathrm{O}_{7}$ are shown. The structures were generated using the VESTA program. ${ }^{34}$

Figure 2: Photographs of the composite material containing $30 \mathrm{wt} \% \mathrm{CeTi}_{2} \mathrm{O}_{6}$ in borosilicate glass after annealing at (a) 750 or (b) $1100^{\circ} \mathrm{C}$ are shown.

Figure 3: XRD patterns from (a) borosilicate glass annealed at 750 or $1100{ }^{\circ} \mathrm{C}$ and (b) Fe-Al borosilicate glass annealed at 750 or $1100{ }^{\circ} \mathrm{C}$ are shown. Diffraction peaks from quartz are marked by an asterisk (*).

Figure 4: XRD patterns from the composite materials containing 10, 20, 30 and $40 \mathrm{wt} \%$ loading of $\mathrm{CeTi}_{2} \mathrm{O}_{6}$ in borosilicate glass annealed at (a) 750 or (b) $1100{ }^{\circ} \mathrm{C}$ are shown. Diffraction peaks from quartz are marked by an asterisk (*).

Figure 5: XRD patterns from the composite materials containing 10, 20, 30 and $40 \mathrm{wt} \%$ loading of $\mathrm{CaZrTi}_{2} \mathrm{O}_{7}$ in borosilicate glass annealed at (a) 750 or (b) $1100{ }^{\circ} \mathrm{C}$ are shown.

Figure 6: Backscattered images from (a) BG-30 wt $\% \mathrm{CeTi}_{2} \mathrm{O}_{6}-750{ }^{\circ} \mathrm{C}$, (b) $\mathrm{BG}-30 \mathrm{wt} \% \mathrm{CeTi}_{2} \mathrm{O}_{6-}$ $1100{ }^{\circ} \mathrm{C}$, (c) BG-30 wt $\% \mathrm{CaZrTi}_{2} \mathrm{O}_{7}-750{ }^{\circ} \mathrm{C}$, and (d) BG-30 wt $\% \mathrm{CaZrTi}_{2} \mathrm{O}_{7}-1100{ }^{\circ} \mathrm{C}$ are shown. The scale bar in each image is $10 \mu \mathrm{m}$.

Figure 7: Ti K-edge XANES spectra from (a) BG-CeTi $\mathrm{O}_{6}-750{ }^{\circ} \mathrm{C}$ and (b) $\mathrm{BG}-\mathrm{CeTi}_{2} \mathrm{O}_{6}-1100{ }^{\circ} \mathrm{C}$ containing 10, 20 and $30 \mathrm{wt} \%$ loading of $\mathrm{CeTi}_{2} \mathrm{O}_{6}$ are shown. The spectrum from $\mathrm{CeTi}_{2} \mathrm{O}_{6}$ is also presented. Feature A represents the pre-edge region $(1 s \rightarrow 3 d)$ and is shown in the inset. Features $\mathrm{B}$ and $\mathrm{C}(1 \mathrm{~s} \rightarrow 4 \mathrm{p})$ represent the main-edge region. The arrows show how the intensity or energy of the spectral features change with decreasing loading of the ceramic in the glass-ceramic composites when compared to the spectrum from $\mathrm{CeTi}_{2} \mathrm{O}_{6}$. 
Figure 8: Ti K-edge XANES spectra from (a) $\mathrm{BG}-\mathrm{CaZrTi}_{2} \mathrm{O}_{7}-750{ }^{\circ} \mathrm{C}$ and (b) $\mathrm{BG}-\mathrm{CaZrTi}_{2} \mathrm{O}_{7}$ $1100{ }^{\circ} \mathrm{C}$ containing 10, 20 and $30 \mathrm{wt} \%$ loading of $\mathrm{CaZrTi}_{2} \mathrm{O}_{7}$. The spectrum from $\mathrm{CaZrTi}_{2} \mathrm{O}_{7}$ is also presented. Feature A (pre-edge region) is shown in the inset. The arrows show how the intensity of the pre-edge feature (A) increased with decreasing loading of the ceramic in the glass-ceramic composites when compared to the spectrum from $\mathrm{CaZrTi}_{2} \mathrm{O}_{7}$.

Figure 9: $\mathrm{Ce}_{3}$-edge XANES spectra from $\mathrm{BG}-\mathrm{CeTi}_{2} \mathrm{O}_{6}$ composite materials containing 10, 20 and $30 \mathrm{wt} \%$ loading of $\mathrm{CeTi}_{2} \mathrm{O}_{6}$ annealed at 750 or $1100{ }^{\circ} \mathrm{C}$ are shown.

Figure 10: $\mathrm{Zr}$ K-edge XANES spectra from $\mathrm{BG}-\mathrm{CaZrTi}{ }_{2} \mathrm{O}_{7}$ composite materials containing 10, 20 and $30 \mathrm{wt} \%$ loading of $\mathrm{CaZrTi}_{2} \mathrm{O}_{7}$ annealed at 750 or $1100{ }^{\circ} \mathrm{C}$ are shown. The spectrum from $\mathrm{CaZrTi}_{2} \mathrm{O}_{7}$ is also presented for comparison.

Figure 11: Si L2,3-edge XANES spectra from (a) $\mathrm{BG}_{-} \mathrm{CeTi}_{2} \mathrm{O}_{6}-750{ }^{\circ} \mathrm{C}$ and (b) $\mathrm{FABG}^{-\mathrm{CeTi}_{2} \mathrm{O}_{6}-}$ $750{ }^{\circ} \mathrm{C}$ containing 10, 20 and $30 \mathrm{wt} \%$ loading of $\mathrm{CeTi}_{2} \mathrm{O}_{6}$ are shown. The spectra are compared to the spectrum from the corresponding glass (BG or FABG).

Figure 12: $\mathrm{Si} \mathrm{L}_{2,3}$-edge XANES spectra from (a) $\mathrm{BG}-\mathrm{CaZrTi}_{2} \mathrm{O}_{7}-750{ }^{\circ} \mathrm{C}$ and (b) FABG$\mathrm{CaZrTi}_{2} \mathrm{O}_{7}-750{ }^{\circ} \mathrm{C}$ containing 10,20 and $30 \mathrm{wt} \%$ loading of $\mathrm{CaZrTi}_{2} \mathrm{O}_{7}$ are shown. The spectra are compared to the spectrum from the corresponding glass (BG or FABG).

Figure 13: Fe K-edge XANES spectra from (a) FABG-30 wt $\% \mathrm{CeTi}_{2} \mathrm{O}_{6}-750$ or $1100{ }^{\circ} \mathrm{C}$, and (b) FABG-30 wt $\% \mathrm{CaZrTi}_{2} \mathrm{O}_{7}-750$ or $1100{ }^{\circ} \mathrm{C}$. The spectra result from $1 \mathrm{~s} \rightarrow 3 \mathrm{~d}$ (feature A) and $1 \mathrm{~s} \rightarrow 4 \mathrm{p}$ (Features B and C) transitions, respectively. The arrows show a shift of the main edge (feature B) to lower energy along with a decrease in the pre-edge peak intensity (feature A) in the composite materials annealed at $1100{ }^{\circ} \mathrm{C}$ versus those annealed at $750{ }^{\circ} \mathrm{C}$. 
Figure 1:

(a)
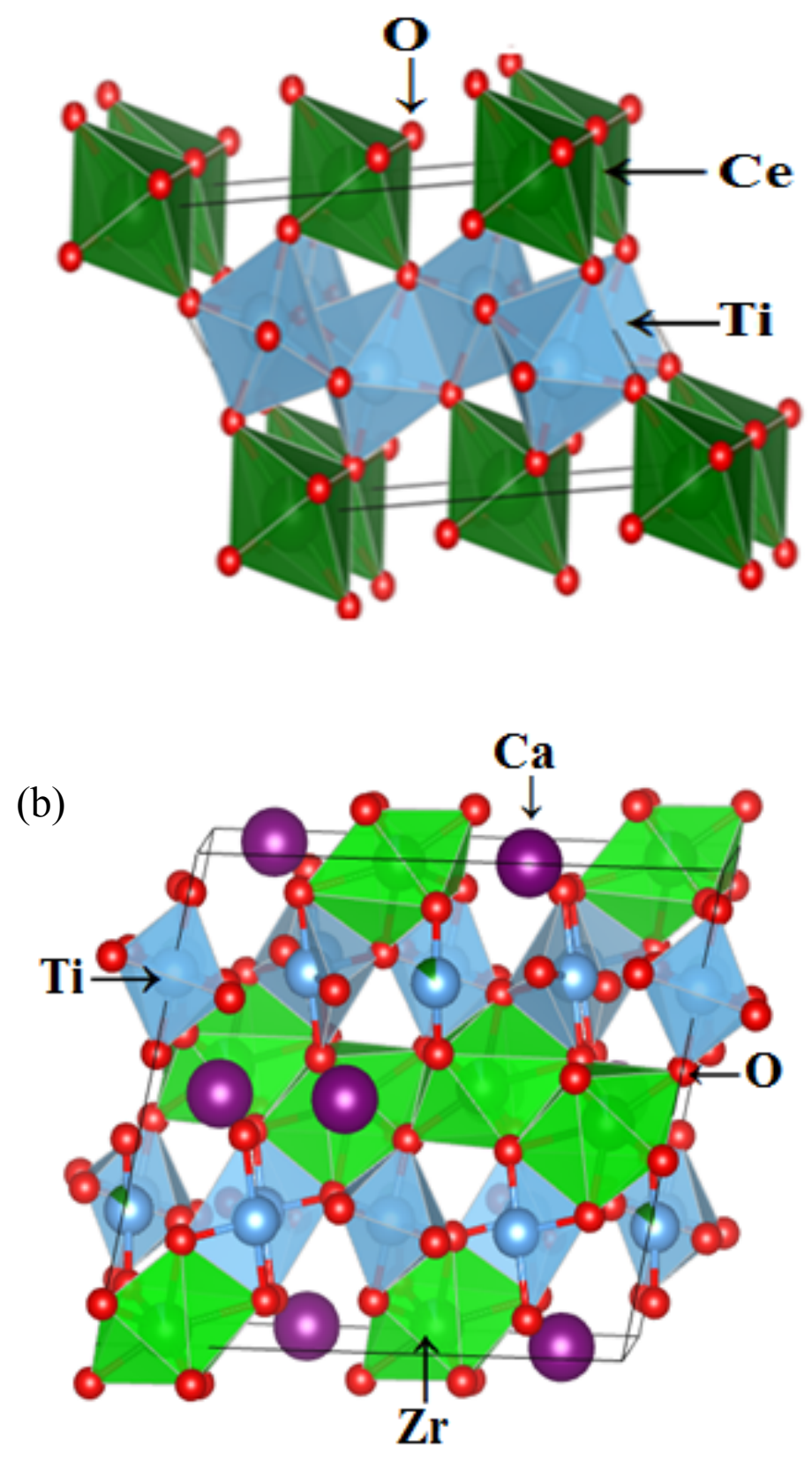
Figure 2:

(a)

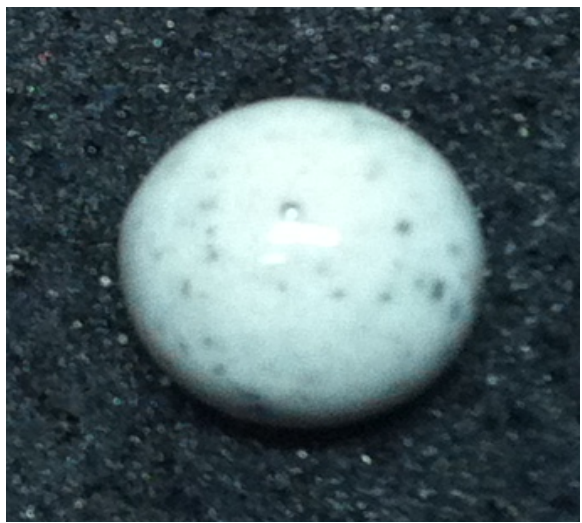

(b)

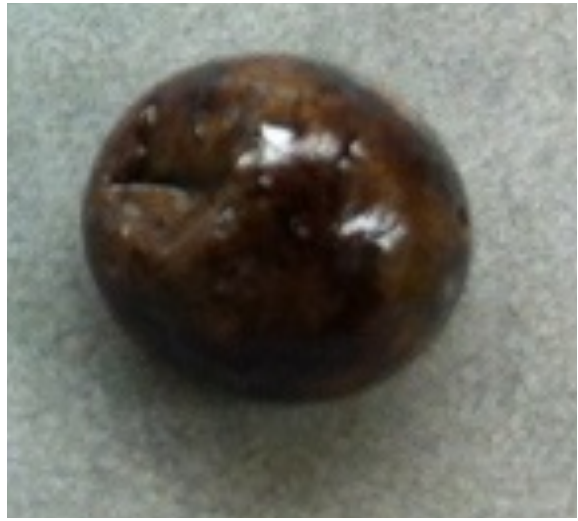


Figure 3:
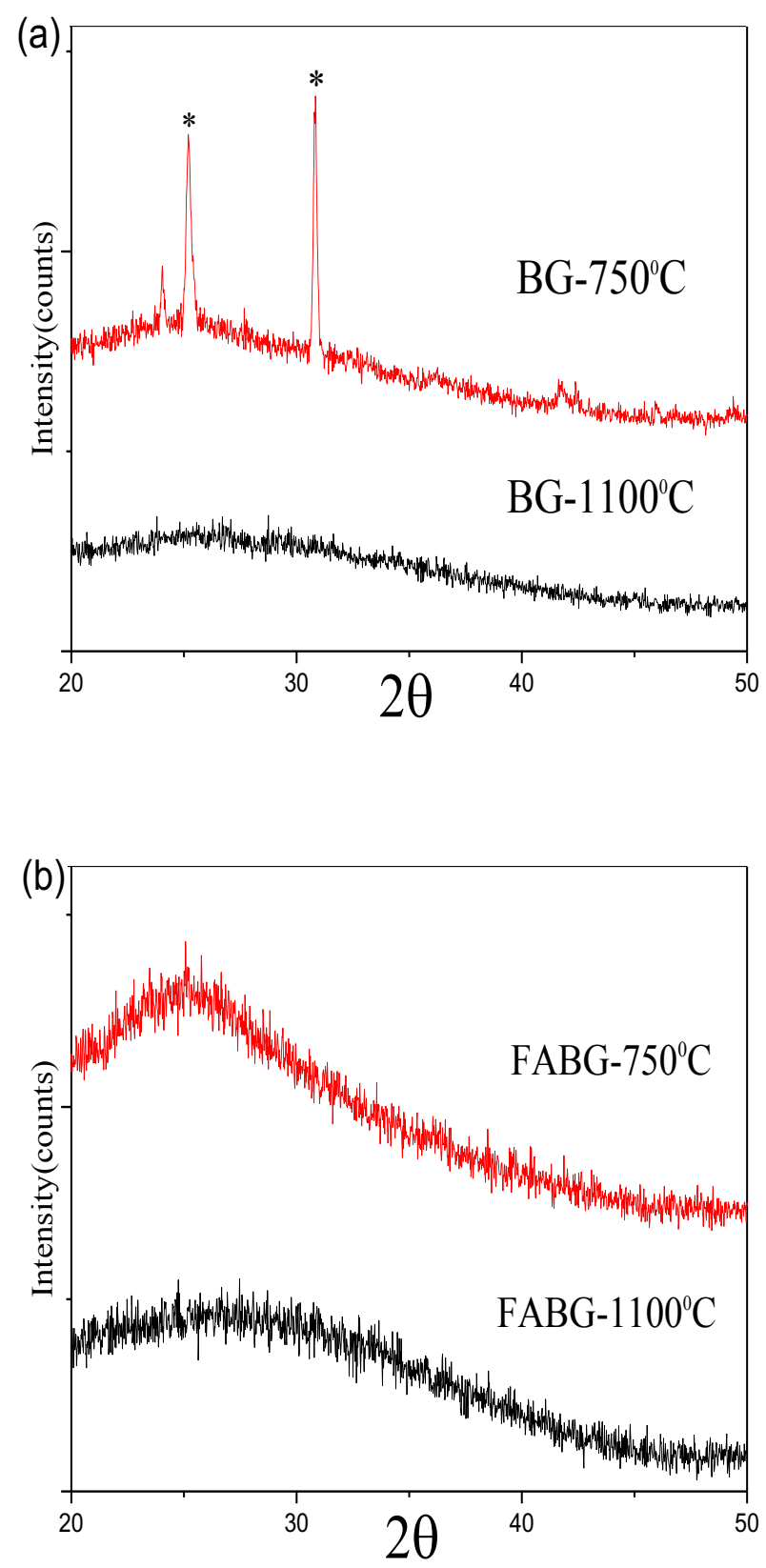
Figure 4:
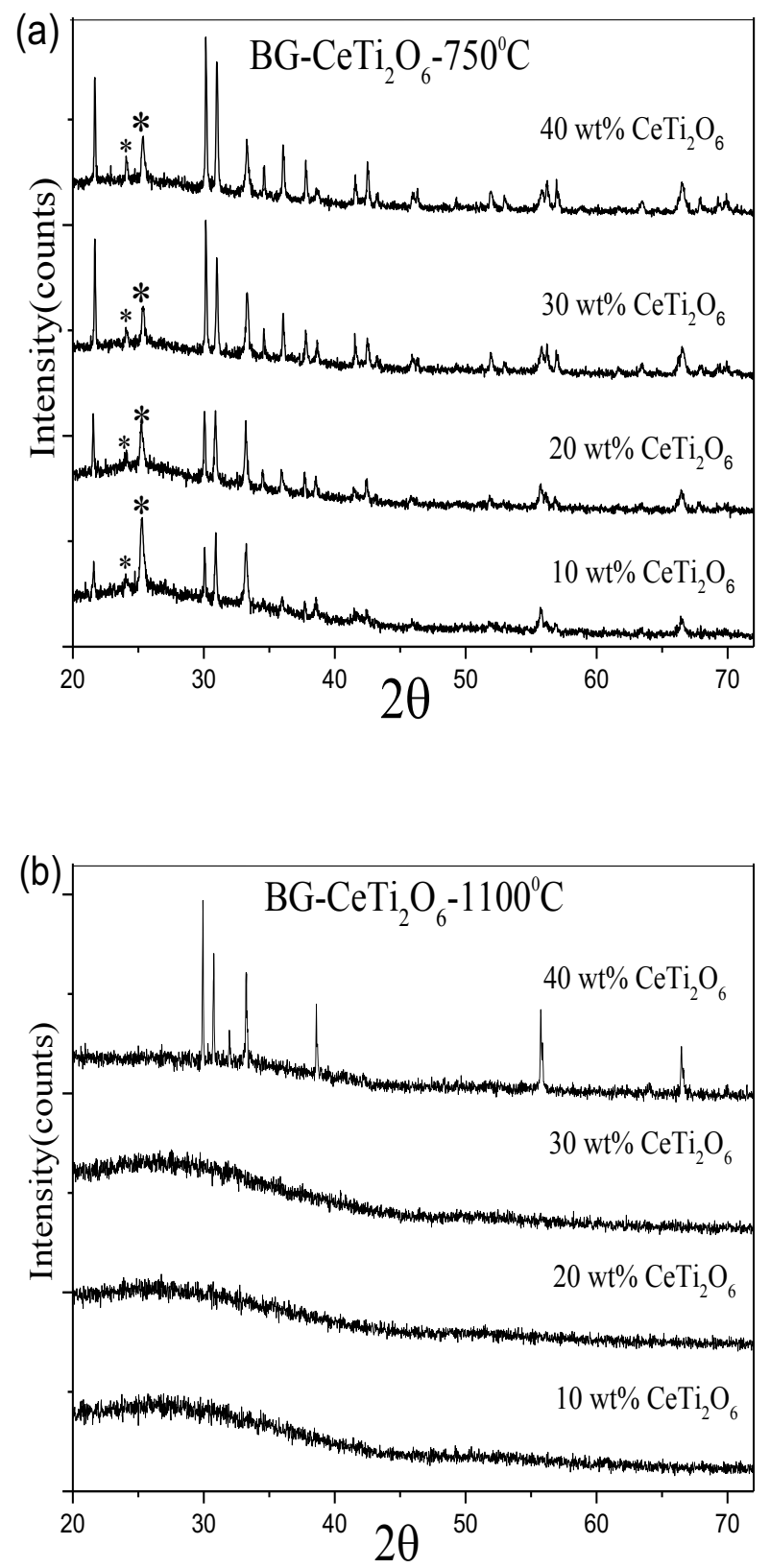
Figure 5:
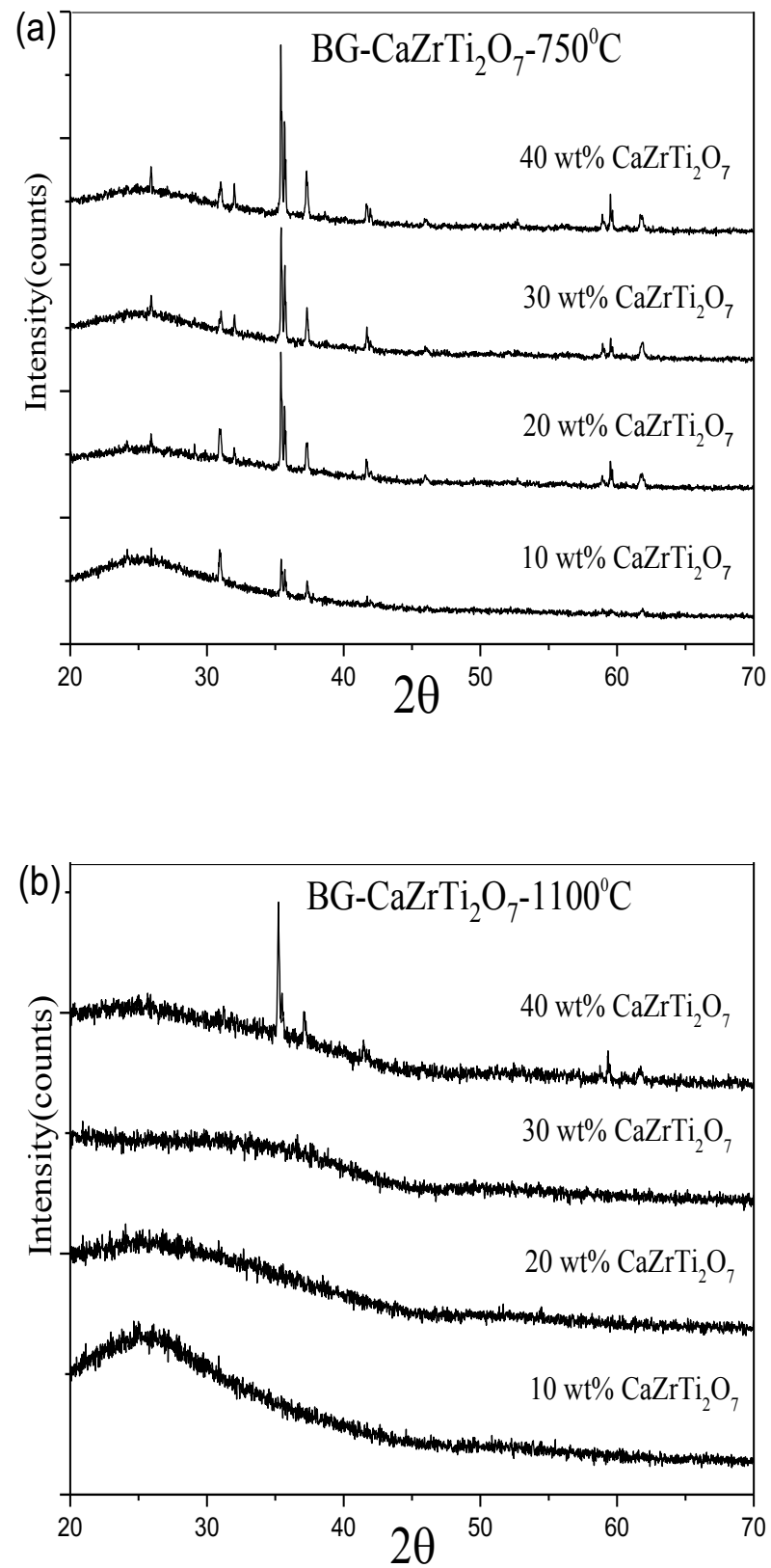
Figure 6:

(a)

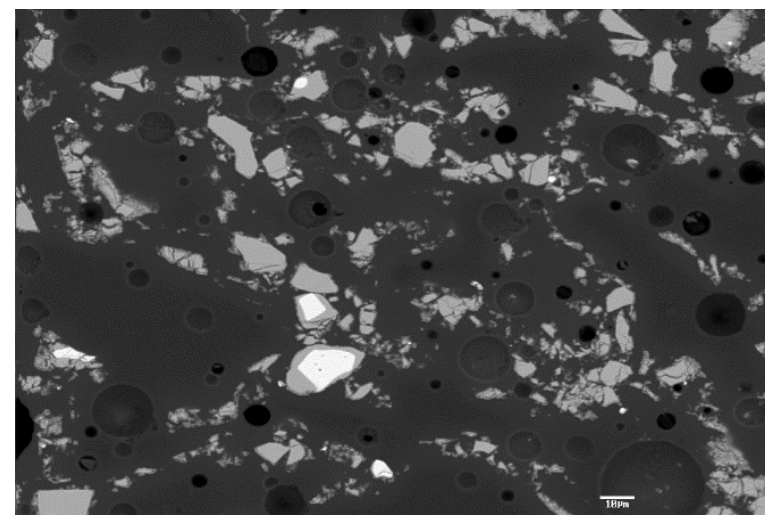

(c)

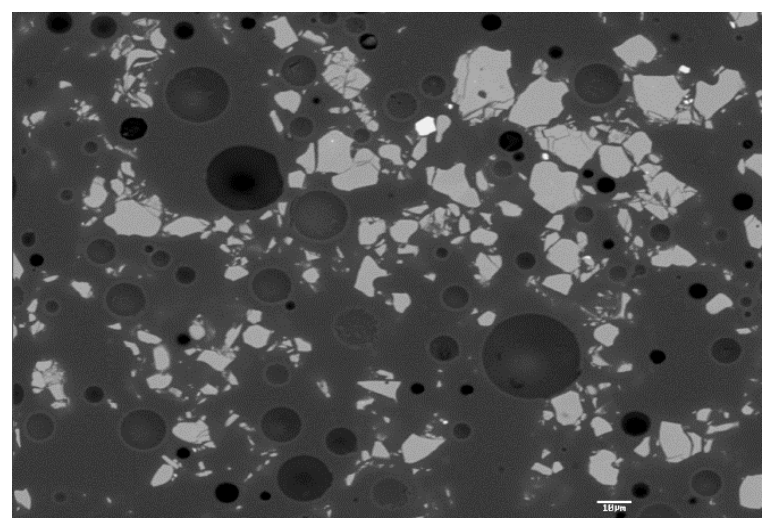

(b)

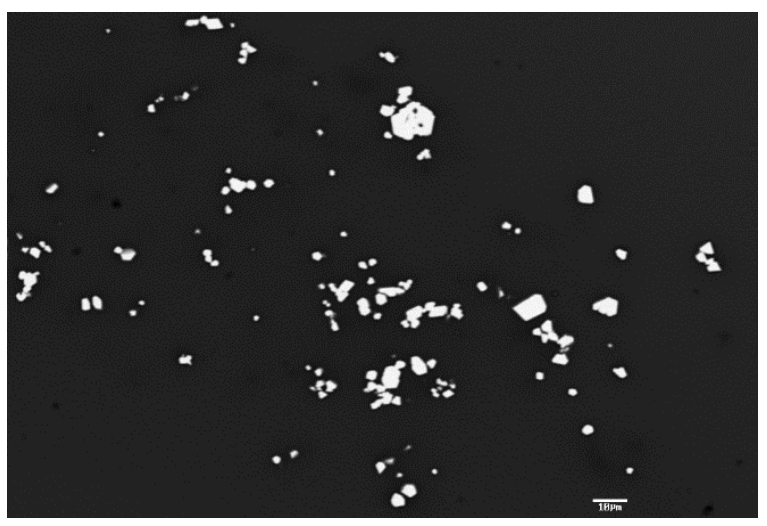

(d)

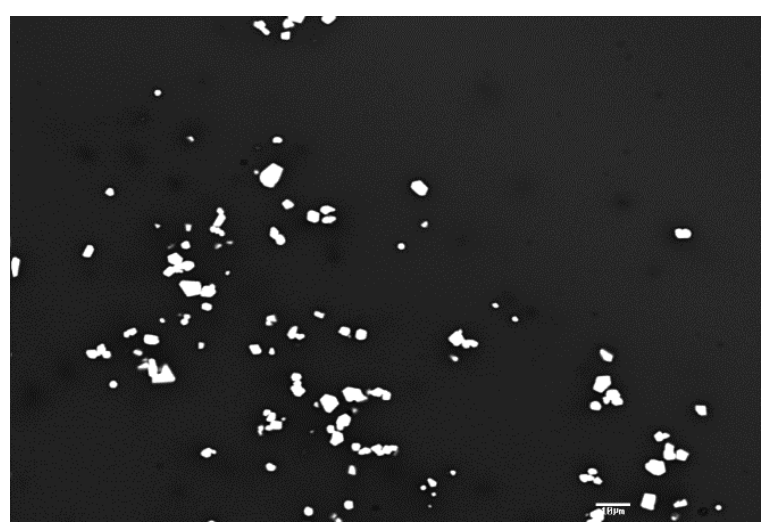


Figure 7:
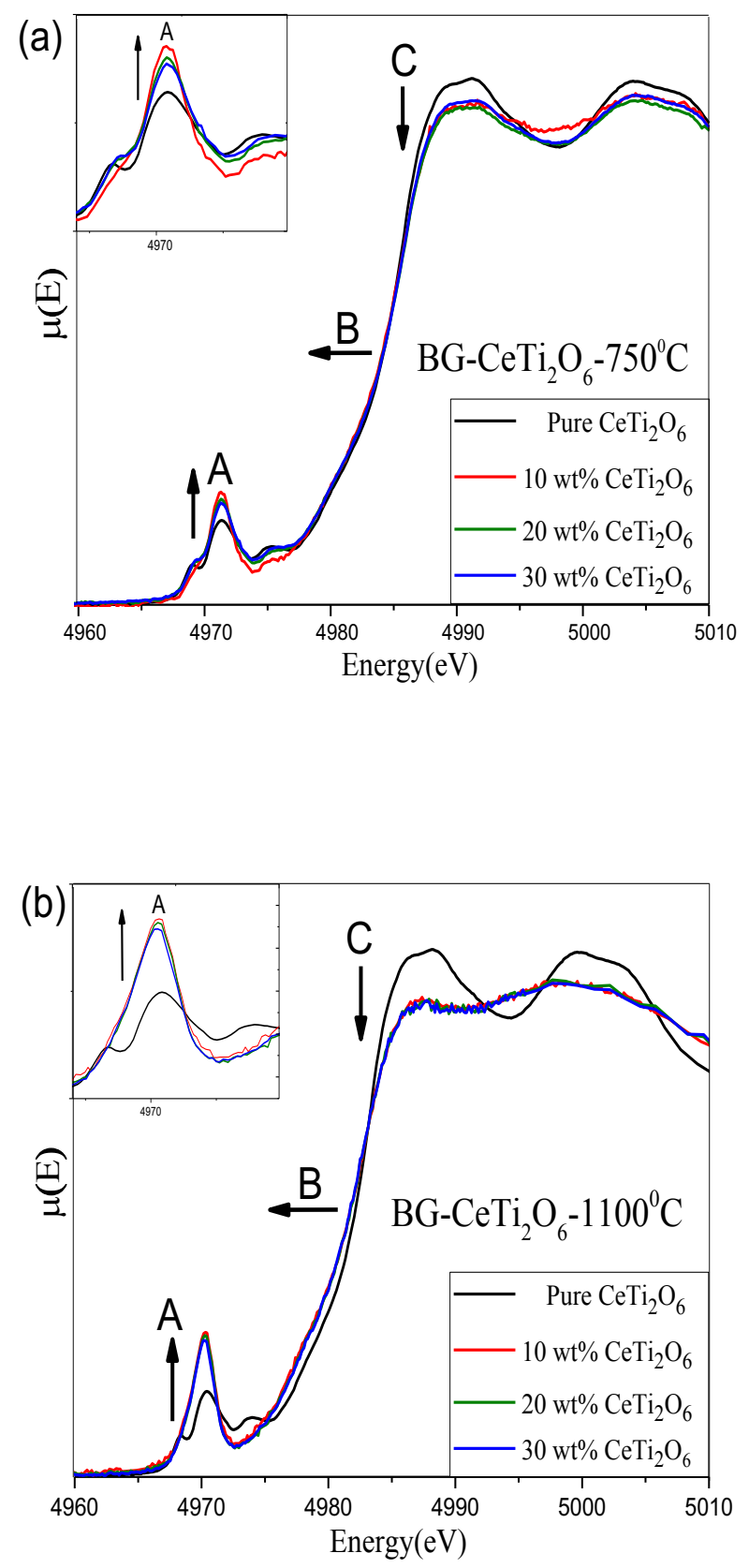
Figure 8:
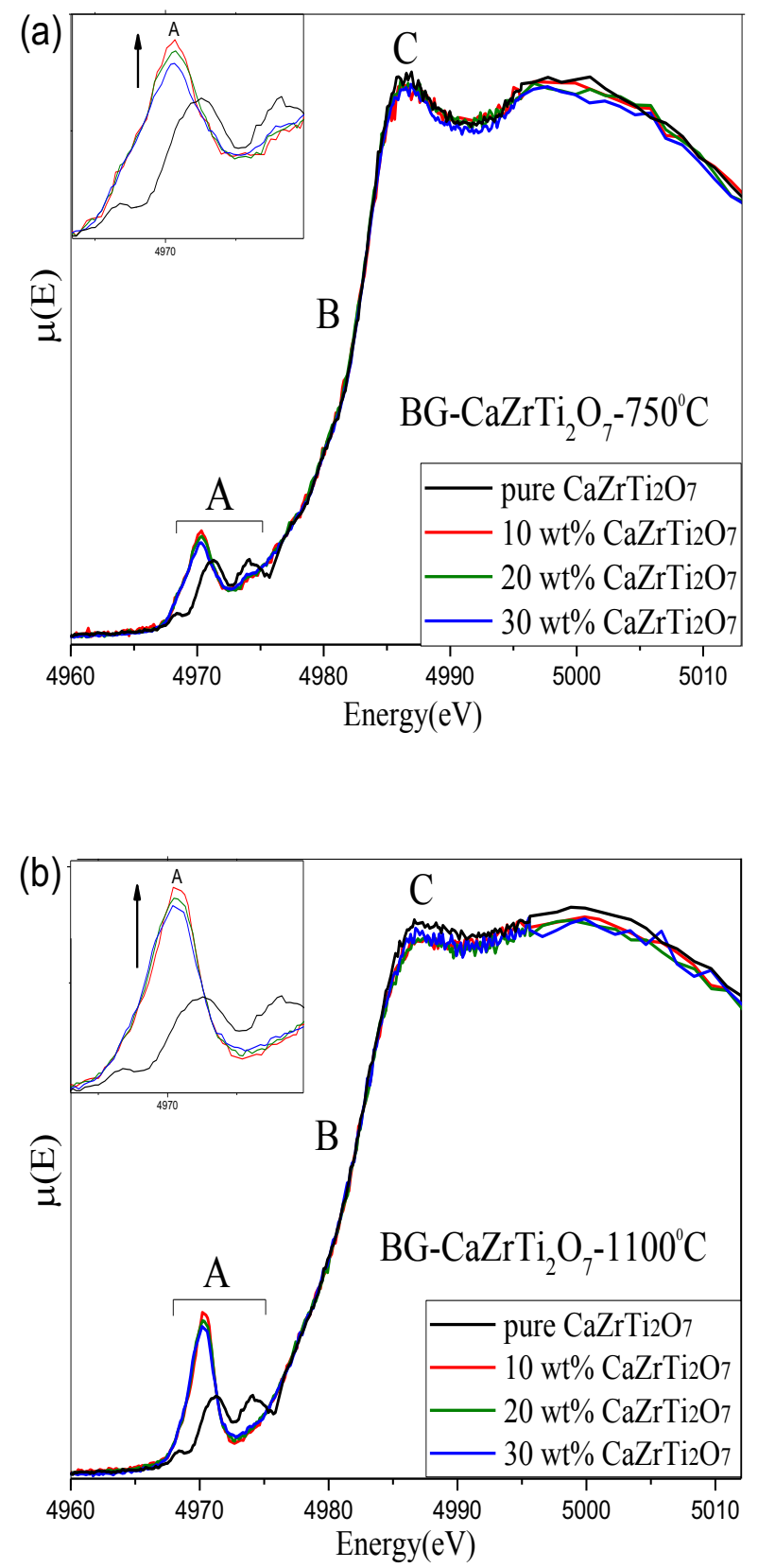
Figure 9:

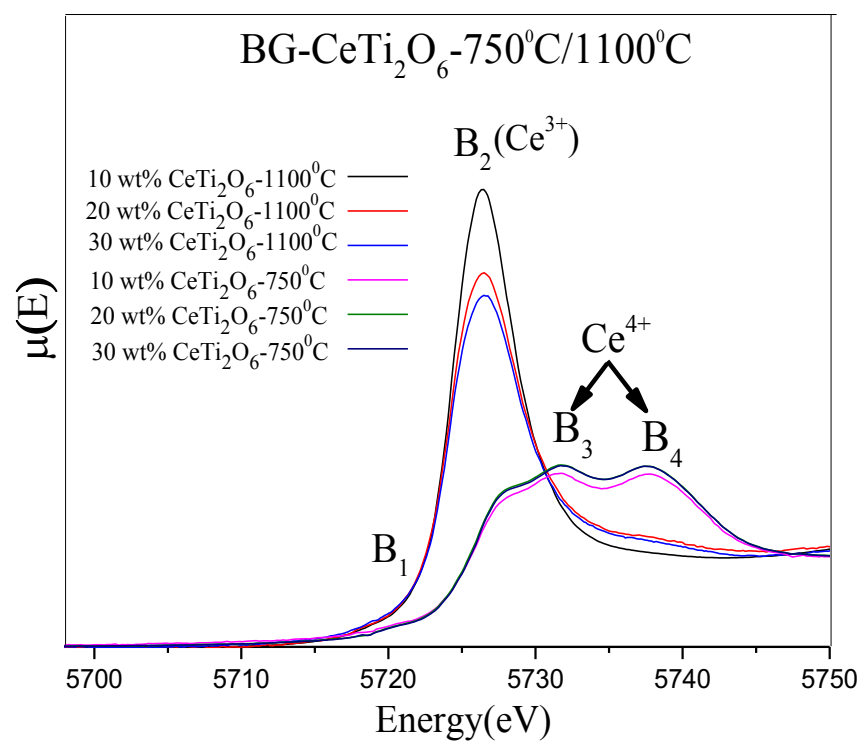


Figure 10:

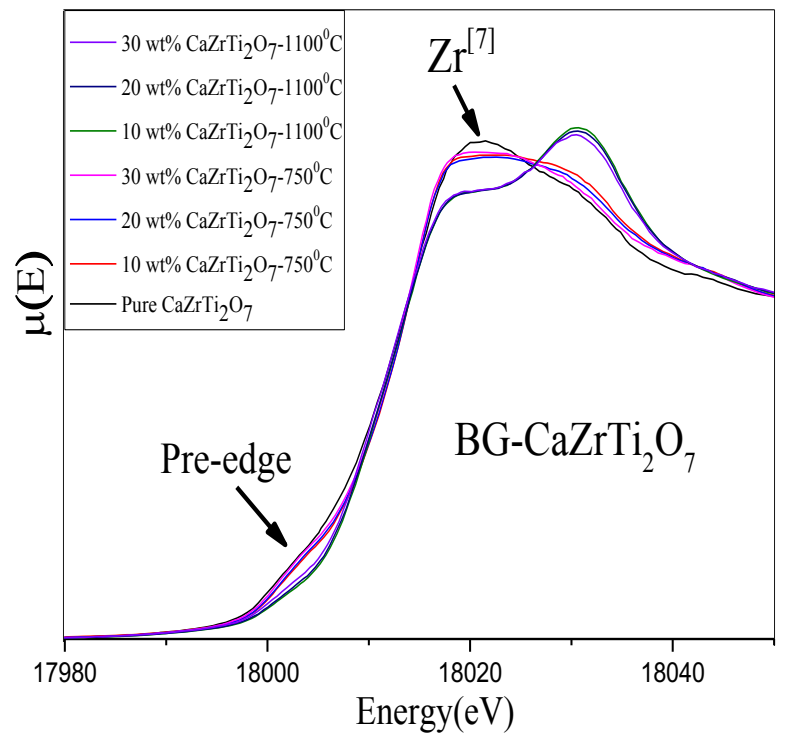


Figure 11:
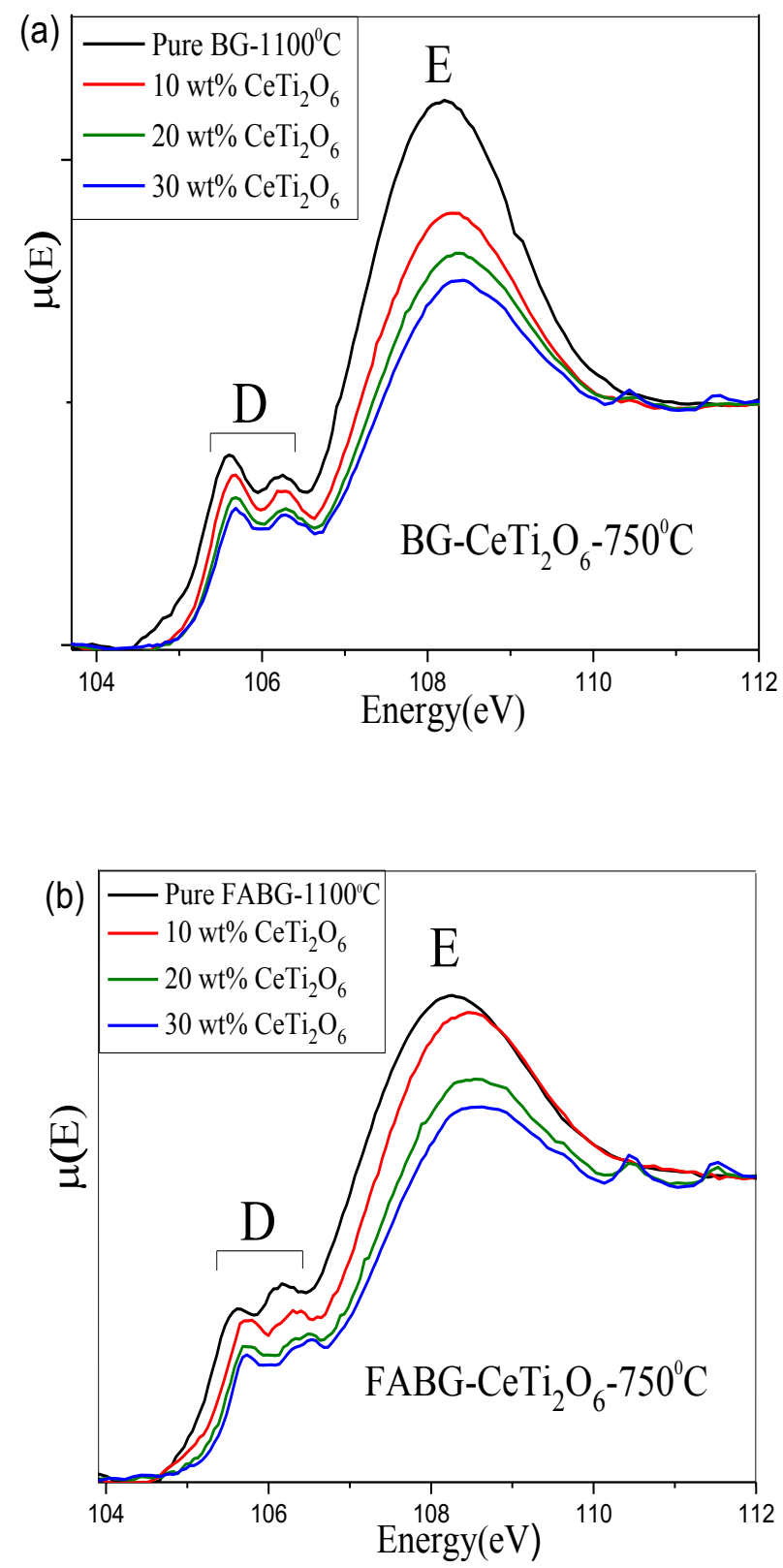
Figure 12:
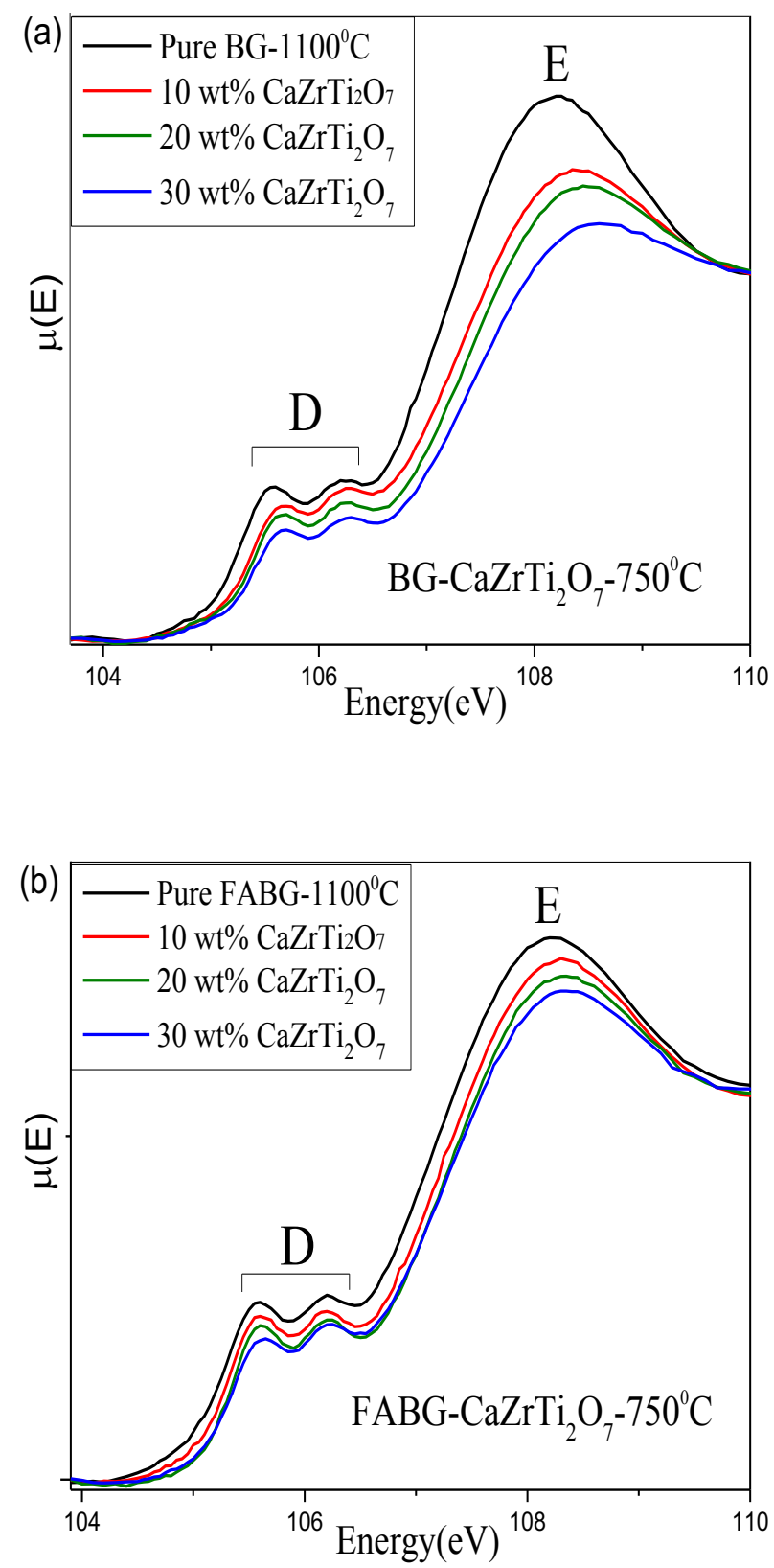
Figure 13:
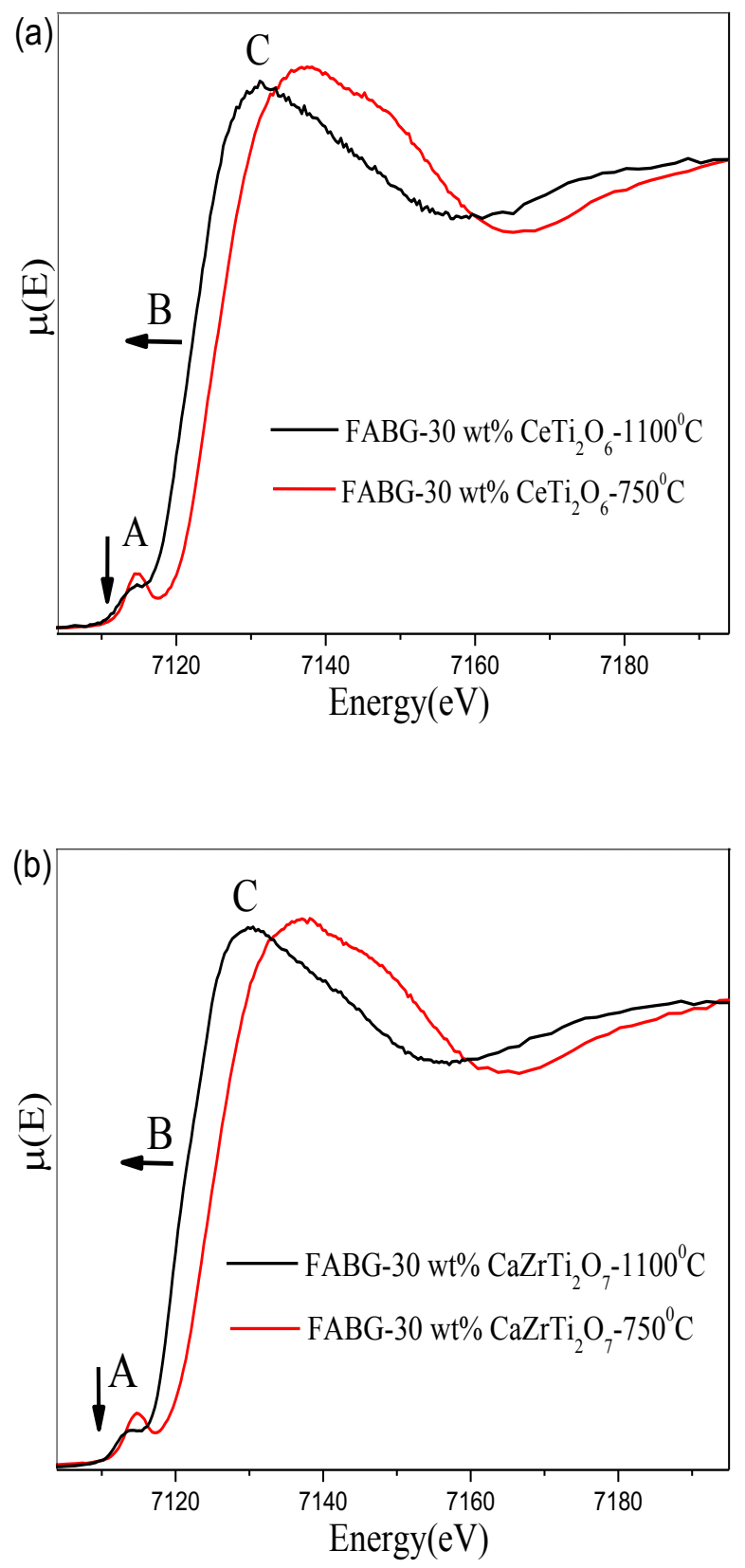